\title{
The processing of root morphemes in Hebrew: Contrasting localist and distributed accounts
}

\author{
Hadas Velan, Ram Frost, and Avital Deutsch \\ The Hebrew University of Jerusalem, Jerusalem, Israel \\ David C. Plaut \\ Carnegie-Mellon University
}

\begin{abstract}
The present paper investigates whether Semitic languages impose a rigid triconsonantal structural principle on root-morpheme representation, by examining morphological priming effects obtained with primes consisting of weak roots. For weak roots, the complete three-consonantal structure is not kept in most of their derivations, and only two letters are consistently repeated in all derivations. In a series of masked priming experiments subjects were presented with primes consisting of the weak roots letters which are repeated in all derivations. The results showed that the two consistent letters of weak roots facilitated the recognition of targets derived from these roots. In contrast, any two letters of complete roots did not facilitate the recognition of complete root derivations. The implications of these results to Parallel-Distributed models and to localist-representational approaches, are discussed.
\end{abstract}

Although lexical structure is traditionally regarded as an interplay of orthographic, phonological, and semantic units, the view that morphological considerations need to be introduced into any model of the mental lexicon has been gaining increasing support. How morphological factors determine lexical organisation is, however, the focus of recent debates. Two contrasting approaches can be outlined to describe the present controversy. The Parallel-Distributed Processing (PDP) view of lexical

Correspondence should be addressed to Ram Frost, Department of Psychology, Hebrew University, Jerusalem 91905, Israel. Email: frost@mscc.huji.ac.il.

This study was supported in part by the Binational Science Foundation Grant 00-00056, and in part by National Institute of Child Health and Human Development Grant HD 01994 to Haskins Laboratories.

(C) 2005 Psychology Press Ltd

http://www.tandf.co.uk/journals/pp/01690965.html

DOI: $10.1080 / 01690960444000214$ 
structure focuses on patterns of activation over processing units that correspond to the orthographic, phonological, and semantic sublexical features of a word. The PDP approach thus argues that there is no level of explicit and discrete representation that corresponds to morphological units. Rather, groups of intermediate or "hidden" units learn to mediate between phonology and semantics or orthography and semantics (e.g., Plaut \& Gonnerman, 2000; Rueckl, Mikolinski, Raveh, Miner, \& Mars, 1997; Seidenberg, 1987). Morphological effects, on this view, reflect a finetuning of the system to the statistical structure that exists among the phonological, orthographic, and semantic properties of words (see Plaut \& Gonnerman, 2000, for a discussion).

In contrast to the present PDP models, the traditional localist framework posits that the lexicon should be modelled through representations at the level of meaningful units. Thus, localist models typically assume that morphemic units are explicitly represented in the mental lexicon, such that morphological representations are discrete and non-distributed. Although some investigators within a localist approach have suggested that all morphologically complex words are listed in the lexicon independently of the base forms from which they are derived (e.g., Butterworth, 1983; Henderson, Wallis, \& Knight, 1984), current opinion is moving more strongly towards some form of morphemic account in which analysis and decomposition occurs for most morphologically complex words (e.g., Baayen, 1991; Burani \& Laudanna, 1992; Caramazza, Laudanna, \& Romani, 1988; Laudanna, Burani, \& Cermele, 1994; Frauenfelder \& Schreuder, 1991; Frost, Forster, \& Deutsch, 1997; Marslen-Wilson, Tyler, Waksler, \& Older, 1994; Schreuder \& Baayen, 1995; Taft, 1994).

Distinguishing between localist and distributed approaches on the basis of pure empirical evidence is not a simple matter. When morphological processing is concerned, the two approaches often yield similar predictions. For example, localist models predict effects of morphological priming, expecting a facilitation that is due to the lexical interconnection between morphologically related words, or alternatively, to the mediation of morphemic units. In contrast, PDP models would predict the same effects, but describe them as a result of weight changes in the connections between the semantic, orthographic, and phonological layers, given the repeated exposure of the speaker to words having similar forms and meanings. Since PDP models focus on the amount of structure between surface forms and meaning, and this measure is continuous and nondiscrete in character, languages having a rich and complex morphological system provide a natural ground for examining the validity of the distributed versus localist approaches.

Research on morphological processing in Hebrew is of special significance in the context of this debate, because of its great richness 
and unique characteristics. Morphological complexity is created in different languages according to different principles. As a rough approximation, the morphological structure of Indo-European languages can be characterised by a linear and sequential concatenation of morphemic units to form multimorphemic words. Thus, both inflectional and derivational morphology is based on appending prefixes or suffixes to a base morpheme, and as a general rule the orthographic integrity of the base form remains intact. In Hebrew, on the other hand, most words can be decomposed into two abstract morphemes: the root and the word pattern. Roots in most cases consist of three consonants, whereas word patterns can be either a sequence of vowels or a sequence consisting of both vowels and consonants. Roots and word patterns are abstract structures because only their joint combination results in specific phonemic word-forms with specific meanings.

The most salient feature of Semitic languages' morphology concerns, however, the special manner with which morphemic units are combined to form morphological complexity. Roots and word-patterns are not appended one to the other linearly, as in languages with concatenated morphology. Rather the consonants of the root are intertwined with the phonemes (and therefore, the corresponding letters) of the word-pattern (see Frost et al., 1997, for detailed description of Hebrew morphology). For example, the Hebrew word /tirkovet/ (meaning "combination"), consists of the combination of the root morpheme r.k.v (conveying the meaning of "combining") with the nominal pattern ti--o-et which conveys the syntactic information that the word is a feminine noun (the dashed lines stand for the places where the root's consonants are to be inserted). The same principle also applies to the verbal system. For example, the word /hirkiv/ (meaning "he combined") is formed by the same root r.k.v interwoven with the verbal pattern hi--i-

Although Hebrew words are basically composed of two morphemes, these morphemic units play different linguistic roles in the derivational system of Hebrew. Whereas the root carries the core meaning of the words, the word-pattern provides mainly grammatical information such as definition of word class. A series of recent studies have employed both masked priming and cross-modal priming to examine the role of roots and word patterns in Hebrew lexical organisation and lexical access (Frost et al., 1997, 2000; Frost, Deutsch, \& Forster, 2000; Deutsch, Frost \& Forster, 1998; Frost, Deutsch, Gilboa, Tannenbaum, \& Marslen-Wilson, 2000). Within the nominal system, when primes and targets shared an identical word-pattern, lexical decisions and naming of targets were not facilitated. In contrast, root primes facilitated both lexical decision and the naming of target words that were derived from these roots. In addition, in a further series of experiments within the verbal system, clear evidence was found 
for a facilitatory priming effect induced by the verbal word-patterns as well as by roots (Deutsch et al., 1998). These results suggest that roots as well as verbal patterns determine lexical organisation and govern lexical access. Thus, they are both recovered from the printed input. However, given the nonconcatenated nature of Hebrew morphology, morphemic units are, in most cases, represented by noncontiguous letters. How exactly are these units recognised in the very brief exposure durations of the masked priming paradigm?

At a first blush, it seems that a necessary condition for fast decomposition of printed words into their morphemic constituents requires a rigid structural system that provides native speakers with reliable cues regarding which letters (or phonemes) of a given word belong to the root and which belong to the word-pattern. For example, one possible cue could be a general constraint that roots in a Semitic language such as Hebrew necessarily include three consonants. When such a structural constraint is adopted, one can easily suggest an algorithm that separates the root letters from the other letters of the printed word with a reasonable error rate. This is because the distribution of the word-pattern letters is highly biased. For example, most word patterns begin with the letters $\mathrm{H}, \mathrm{M}$, T, or N. Many of them end with the letter T, etc. When the distributional properties of word-pattern letters are considered along with the requirement that three letters should be allocated to the root-morpheme, in most cases a single solution for parsing a printed word into a root and a word-pattern emerges.

To examine the possibility that Hebrew readers use constraints such as a tri-consonantal structure, Frost et al. (2000) employed a special subset of verbal forms that poses a genuine difficulty in parsing. These forms are labelled in Hebrew "weak roots". Weak roots are roots in which the complete three-consonantal structure is not kept in some of the derivations. These belong to two main classes: defective roots, characterised by an assimilation of one consonant in certain derivations, and mute roots, in which one consonant is almost never pronounced and becomes a quiescent letter in print. This is because of some linguistic processes (such as sound shifting analogies in derivation or conjugation, and phonetic assimilation). Although the phenomenon of weak roots seems to be a peculiar case anchored in phonetic and historical linguistic processes, we should emphasize that there are many weak roots in Hebrew (about $10 \%$ of the roots), and many of them form common, frequently used verbs.

In the defective roots, when the weak radical (usually the initial consonant $/ \mathbf{n} /$ ), has a zero vowel (a quiescent schwa), it is assimilated into the following phoneme. This phonetic process is systematic and occurs always at the same phonetic environment, i.e., it will always occur in the 
same word patterns whether they are nominal or verbal. ${ }^{1}$ The only clue to this assimilation is the gemination of the following (second) consonant. The phonetic expression of the gemination is of an emphasised articulation. However, in Modern Hebrew, only three consonants have preserved this phonetic emphasis, the fricative consonants $/ \mathbf{v} /, / \mathbf{x} /$, and $/ \mathbf{f} /$ (represented by the letters $\boldsymbol{\beth}, \boldsymbol{\supset}$, and $\boldsymbol{\nabla}$ respectively), which change to stops once geminated (namely change to $/ \mathbf{b} /, / \mathbf{k} /$, and $/ \mathbf{p} /$ respectively). Orthographically, the gemination is marked by a diacritical point, which is inserted into the geminated consonant. Hence, in unpointed Hebrew the gemination remains unmarked (Berman, 1978; Blaue, 1971).

Since the phonetic and orthographic clues indicating the consonantal assimilation are not reliable in Modern Hebrew in both modalities (the change of articulation in the spoken form, and the diacritic mark in the written form), the end result is a "missing" consonant or letter in both the spoken and the visual modalities. Moreover, even if the gemination marking would have existed, the gemination by itself does not reveal the identity of the consonant which was assimilated. As a consequence, without specific training in linguistics, the existence of a defective root radical in the form is far from being obvious to any naïve speaker. However, the identity of the "missing" consonant could be revealed, by considering the quasi-regular appearance of the missing consonant. This is because the defective roots may appear as complete forms in some derivations, and readers may use this information to identify the consonant that is missing in the weak forms. For example, when the Hebrew root n.p.l (conveying the action of falling) is conjugated in the causative verbal pattern hi- -i-, the verbal form /himpil/ changes to /hipil/, and the identity of the missing consonant becomes obscure. However, since the conjugation of the same root with the reflexive verbal pattern hit-a-e- produces the form /hitnapel/, Hebrew speakers may gain some cues regarding the missing consonant in /hipil/.

The mute roots present an entirely different case. There are three different kinds of mute roots, and those are classified according to the specific radical and the position of the mute radical in the root (the first, the second, or the third phoneme of the root). The weak radicals are always one of the semi-vowel consonants $/ \mathbf{y} /$ or $/ \mathbf{w} /($ the letters $/ 9)$ or the plosive or fricative glottal consonant $/ \mathbf{\gamma} /$ or $/ \mathbf{h} /$ (the letters $\mathbf{k} / \boldsymbol{\pi})$. Once a mute root is embedded in a word pattern (either verbal or nominal), the metric structure of the word pattern changes, because of the unpronounced radical. The scope of the metrical change may vary, depending on the

\footnotetext{
${ }^{1}$ For example, assimilation of the radical /n/ occurs in the following conjugations in Modern Hebrew: hif'il, huf'al, nif'al (in the past and present tense), and pa'al/kal (only in the future tense).
} 
specific weak radical and the specific word-pattern. These metrical changes usually also entail some changes in the vowel structure of the wordpattern. For example, the regular form of the complete root r.g.s ("to feel") conjugated with the verbal pattern hi- -i- is a two syllabic CVC-CVC word, /hirgish/ ("he felt"). However when the same verbal pattern is conjugated with a mute root like b.y.n ("to understand") which has the weak radical ' $\mathbf{y}$ ' in second position, the conjugated form is /hebin/ with the metric structure of CV-CVC, and a different vowel in the first syllable. The same verbal-pattern conjugated with the root g.l.h, ("to deport") in which the weak radical is the third radical, /h/, becomes /higla/ with the metric structure of CVC-CV, and a different vowel in the second syllable. The circumstances are even more complicated because in many cases there are alterations between the two semi-vowels $/ \mathbf{y} /$ and $/ \mathbf{w} /$ within one root so that the same root will appear in print in some occasions with the quiescence letter $/ \mathbf{y} /$ and in other occasions with the quiescent letter /w/. Similarly, in the few cases when the weak radical is pronounced and the derived form appears as a complete root, the weak radical can be pronounced sometimes as $/ \mathbf{y} /$ and sometimes as $/ \mathbf{w} /$. Thus unlike the defective roots, in which the specific identity of the weak radical can be unequivocally inferred from the cases in which the root appears in its complete form, the identification of the weak radical in the mute root is much more complicated and is not unequivocal. Another complication comes from the written manifestation of the mute roots. Apparently, the weak radical is explicitly presented in the written form of the word as a quiescent letter.

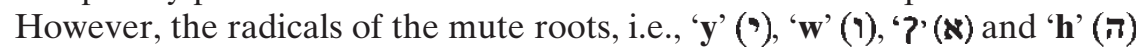
serve also as vowel letters in Hebrew to denote each of the five vowels ( $/ \mathrm{i} /$, $/ \mathrm{e} /, / \mathrm{o} /, / \mathrm{u} /$, and $/ \mathrm{a} /$ ) that exist in Modern Hebrew. Consequently, the appearance of these letters in the mute root can be perceived by the naïve reader of the language as representing the vowel of the syllable rather than the mute radical. In sum, the existence of a weak radical in the mute root and its specific identification is a very vague matter, which is almost impossible to decipher for the native speaker of the language. This is because of three main reasons. First, the great variety in the metrical changes in the various root derivations given the location and identity of the specific weak phoneme of the root. Second, the alternations between the weak radical within one root, and third, the confounding with vowel letters in printed forms. These characteristics are in sharp contrast to the defective roots, in which the metrical changes are very consistent and thus probably more transparent (Berman, 1978; Blau, 1971).

To explore the process of morphological decomposition in Hebrew, Frost et al. (2000) used weak-root derivations in a series of experiments. These experiments revealed that the robust verbal-pattern priming effects in Hebrew (Deutsch et al., 1998), could not be obtained if primes and/or 
targets consisted of weak root derivations. Thus, when one consonantal letter was missing in the derived forms, subjects did not seem to be able to retrieve the verbal-pattern of the printed word. More importantly, once the weak forms were made to be complete by inserting a random consonant into their phonological structure thereby forming a pseudoverb, the verbal-priming effect re-emerged. These findings were interpreted to suggest that, in contrast to derivations composed of full forms, derivations composed of weak roots do not undergo morphological decomposition. Frost et al. (2000) thus argued that weak root forms present a genuine parsing problem to the native speaker. For if three consonants of the form are assigned to the root, there would be one missing for the verbal-pattern, and if all the correct consonants are assigned to the verbal-pattern morpheme, there would be only two consonants left for the root. This would violate the formal tri-consonantal structural representational constraint presumably adopted by the reader of Hebrew.

The present paper is thus concerned with the following question: Do Semitic languages indeed impose a rigid tri-consonantal structural principle on root-morpheme representations? Note that this question is not simply relevant for describing the psycholinguistic constraints imposed on any model of morphological processing of Hebrew. More importantly, it concerns whether distributed models will be able to account for the full range of morphological effects in languages with rich morphological systems (see Plaut \& Gonnerman, 2000, for discussion). One major difference between distributed and localist approaches concerns whether behaviour is characterised as rule-based or not. Localist models typically regard the occurrence of morphological priming as a discrete cognitive event that reflects the existence or nonexistence of morphological connections. By contrast, PDP models focus on the amount of statistical structure between inputs and outputs, which is fundamentally continuous in nature. Thus, in general, any morphological effect that appears to have an all-or-none character constitutes an important, although not necessarily insurmountable challenge to the distributed approach (see also Marcus, Brinkmann, Clahsen, Weise, \& Pinker, 1995). For example, returning to the context of Hebrew morphology, the fact that the robust verbal-pattern priming observed when stimuli have structurally intact three-consonant roots, totally collapses when primes or target contain only two root consonants, seems, on the face of it, more compatible with a rule-based processing system than with a distributed system.

This conclusion, however, may be premature and requires further empirical examination. The claims regarding distributed systems were based entirely on the failure to obtain a verbal-pattern priming effect with weak roots. The logic of this investigation was that the verbal-pattern priming effect necessarily reflects morphological decomposition, and if 
morphological decomposition cannot be demonstrated for weak roots then they are not represented as morphemic units in the Hebrew lexicon. It is possible, however, that although weak-root forms are not decomposed as fast as full forms, Hebrew speakers are nevertheless sensitive to the two consonants that are repeated in all of the weak-roots' derivations. The possibility that the two repeated letters of weak roots have a special lexical status relative to the other letters was not directly examined by Frost et al. (2000). The present research was aimed at conducting this investigation.

In a series of masked priming experiments, subjects were presented with primes consisting of the letters of mute and defective roots. We measured whether these letters facilitated the recognition of targets derived from those roots. The previous study on weak roots (Frost et al., 2000) did not differentiate between mute and defective roots. However, models of distributed representations have clear and differential predictions regarding their processing. First, PDP models suggest that the two consonants that are repeated in all derivations of mute and defective roots will reveal morphological priming effects. Similarly they suggest that the "formal" three consonants of mute roots will not reveal priming. This is because the third consonant does not have any consonantal (and therefore) explicit formal realisation. Finally, they predict that the three consonants of defective roots will reveal morphological priming effects, at least to some extent. This is because the third consonant appears in many of the derivations although not in all of them.

In contrast to prediction of the distributed approach, the view that Semitic languages impose a rigid structural constraint on the representation of root morphemes suggests that any primes consisting of two letters rather than three will not facilitate the recognition of derived targets. On this localist view, no difference is expected between mute and defective roots: none of them will reveal morphological priming.

\section{EXPERIMENT 1}

In Experiment 1, we investigated the processing of mute roots. The aim of the experiment was to examine whether a prime consisting of the two rootletters that are repeated in all of the root derivations can facilitate lexical decisions to the root derivations. Subjects were presented with target words, all mute-root derivations, which were paired with three different primes: in the related condition, the primes were the two repeated letters of the mute roots. In the orthographic control condition, the primes for the same targets were two letters contained in the targets, but not the two repeated root letters. Finally, in the identity condition the primes were identical to the targets. The purpose of the identity condition was to obtain a baseline for the maximal priming effect when the targets are primed by 
themselves. As in previous studies, facilitation in the related condition was assessed relative to the orthographic control condition in which an orthographic but not a morphological relationship existed between primes and targets. Greater facilitation for the two repeated root-letters would suggest that these letters have a special status relative to other letters of the targets.

\section{Method}

Participants. The participants were 48 undergraduate students at the Hebrew University, all native speakers of Hebrew, who took part in the experiment for course credit or payment.

Stimuli and design. The stimuli consisted of 48 target words. All targets were nouns which were derived from mute roots. Targets were four to six letters long, and contained two or three syllables with four to seven phonemes. Their mean number of letters was 4.73 and their mean number of phonemes was 5.46. The words were root derivations that were combined with a variety of common word patterns in Hebrew. The target words were paired with 48 primes to create three experimental conditions: in the identity condition, primes and targets were the same word. In the related condition, the primes consisted of the two letters of the root that are repeated across all the various derivations of the root, and the targets were the root derivations. In the control condition, the primes consisted of a sequence of two letters contained in the target, which were not the two letters of the root (although one root letter could be present). An example of the stimuli used in the experiment is presented in Table 1, the stimuli are presented in Appendix B. Similar to the word targets, the nonwords were also divided into three experimental conditions, identity, pseudorelated, and control.

TABLE 1

Examples of the stimuli used in Experiment 1 in the identity, related and control conditions. Stimuli are derived from mute roots

\begin{tabular}{|c|c|c|c|}
\hline & Identity & Related & Control \\
\hline Mask & \#\#\#\#\#\#\# & \#\#\#\#\#\#\# & \#\#\#\#\#\#\# \\
\hline \multirow[t]{4}{*}{ Prime } & $\begin{array}{l}\text { /hokara/ } \\
\text { (respect) }\end{array}$ & & \\
\hline & y.q.r (ר.ק.") & & \\
\hline & hwqrh & $\mathrm{qr}$ & $\mathrm{hq}$ \\
\hline & הוקרה & קר & הק \\
\hline \multirow[t]{2}{*}{ Target } & hwqrh & hwqrh & hwqrh \\
\hline & הוקרה & הו'קרה & הוקרה \\
\hline
\end{tabular}


The stimuli were divided into three lists. Each list contained 16 words and 16 nonwords in each of the three experimental conditions. The stimuli were rotated within the three conditions in each list in a Latin Square design. Sixteen different participants were tested in each list, performing a lexical decision task. This procedure allowed each participant to provide data points in each condition while avoiding stimulus repetition effects.

The stimuli in Experiment 1, as well as in all other experiments of the present study, were presented in unpointed Hebrew characters. Unpointed script was used because this is the way in which adults read Hebrew. Since we employed unpointed print, some of our letter-pairs in the related and the control conditions could be read as words. For example, the two letters 'QR' could have been read as /kar/ meaning "cold". Previous studies from our laboratory suggested that prime lexicality does not affect masked morphological priming in Hebrew (e.g., Frost et al., 1997, Expt 3). However, to ensure that prime lexicality did not introduce a confound in our study, we calculated the number of times the primes could be read as words in the related and the control conditions, for the purpose of conducting post hoc-analyses. The number of possible word readings was 41 in the related condition, and 19 in the control condition.

Procedure and apparatus. The experiment was conducted on an IBM Pentium computer. The software used for presentation of stimuli and for measuring the reaction times was the DMDX display system developed by K. I. Forster and J. C. Forster at the University of Arizona. Each trial consisted of three visual events. The first was a forward mask consisting of a row of seven hash marks, which appeared for 500 ms. The mask was immediately followed by the prime, with an exposure duration of $40 \mathrm{~ms}$. The prime was in turn immediately followed by the target word, which remained on the screen for an additional $1000 \mathrm{~ms}$. The time lag between the subject's response and the next stimuli was $1000 \mathrm{~ms}$. All visual stimuli were centred in the viewing screen and were superimposed on the preceding stimuli. Although only the Hebrew square font was used, two versions of this font, which differed in their relative size, were included. Targets were always presented in the larger font $(20 \%$ larger than the primes). This guaranteed complete visual masking of the primes by the targets and made the primes and the targets physically distinct stimuli.

\section{Results and discussion}

The reaction times (RTs) were averaged for correct responses in the three experimental conditions across participants and across items. Within each participant, RTs that were outside a range of 2 SD from the participant's mean were curtailed. Establishing cutoffs of $2 \mathrm{SD}$ above and below the 
mean for each participant minimised the effect of outliers. Any RTs exceeding these cutoffs were replaced by the appropriate cutoff value. Trials on which an error occurred were discarded. This procedure was repeated in all of the following experiments. The effect of the identity and related primes were assessed relative to the control baseline. The results are presented in Table 1a. Lexical decisions to targets were facilitated in the identity condition $(32 \mathrm{~ms})$ when the primes and the targets were the same word. The more interesting results, however, concern lexical decisions to target words with morphologically related primes. When primes consisted of the two letters repeated in all derivations, a significant facilitation of $13 \mathrm{~ms}$ was obtained.

The results were subjected to a two-way analysis of variance (ANOVA) in which the prime condition was one factor, and the word list was the other. This procedure was used in all of the following experiments, but only the main effect of the prime will be reported because the list variable was introduced merely to extract any variance due to counterbalancing.

The prime-condition factor was significant in both the participants and the item analyses, $F_{1}(2,90)=36.17, M S E=348, p<.001 ; F_{2}(2,90)=20$, $M S E=637, p<.001$. Planned comparisons revealed that the difference between the related and the control conditions was significant for both participants and items, $F_{1}(1,45)=14.29, M S E=303, p<.001 ; F_{2}(1,45)=$ 7.69, $M S E=604, p<.008$. The error analysis revealed a non-significant prime condition factor for both participants and items, $F_{1}(2,90)=1.46$, $M S E=36, p<.238 ; F_{2}(2,90)=2.02, M S E=26, p<.138$. The prime condition for nonwords revealed a significant effect for participants but not for items, $F_{1}(2,90)=3.18, M S E=475, p<.046 ; F_{2}(2,90)=1.47, M S E=$ $814, p<.236$. No effect was found for errors for nonwords, $F_{1}(2,90)=2.4$, $M S E=42, p<.096 ; F_{2}(2,90)=2.46, M S E=42, p<.092$. In general, priming does not occur reliably for nonword targets under masked presentation. This is because facilitation in this paradigm is considered to reflect lexical processes, depending on the existence of a lexical representation (Forster, 1987; Forster \& Davis, 1984; Forster et al. 1987).

TABLE 1a

Reaction times (RTs, in ms, and per cent errors for lexical decision to target words and nonwords in the identity, related and control conditions of Experiment 1

\begin{tabular}{ccccccc}
\hline & Words & & & \multicolumn{3}{c}{ Nonwords } \\
\cline { 1 - 2 } \cline { 5 - 7 } Identity & Related & Control & & Identity & Related & Control \\
\hline 546 & 565 & 578 & & 624 & 626 & 634 \\
$4.2 \%$ & $5.6 \%$ & $6.4 \%$ & & $8.4 \%$ & $5.6 \%$ & $7.5 \%$ \\
$\mathbf{+ 3 2}$ & $\mathbf{+ 1 3}$ & & & $\mathbf{+ 1 0}$ & $\mathbf{+ 8}$ & \\
\hline
\end{tabular}


To ensure that prime lexicality did not affect our results, we compared response latencies when the two-letter primes could be read as a word and when they could not. Planned comparisons revealed that lexical decisions to the targets did not differ significantly when the two-letter primes were words or not, in both the related and the control conditions, $t(46)=0.5, p$ $<.6 ; t(46)=0.2, p<.8$; respectively. These results are similar to the findings reported by Frost et al. (1997).

The striking result of Experiment 1 is that primes consisting of the two letters of a mute root that are repeated in all of the root derivations facilitated the recognition of targets derived from these roots. This outcome demonstrates that the two repeated letters have acquired a lexical role that is different from all other letter combinations. From a representational perspective, the results of Experiment 1 suggest that, at least when mute roots are considered, a tri-consonantal structural principle is not necessarily imposed on root-morpheme representation.

\section{EXPERIMENT 2}

In Experiment 2, subjects were presented with primes consisting of the three formal letters of the mute roots. It should be emphasised that the linguistic origin of the three consonants of mute roots is well-defined in Hebrew grammar. ${ }^{2}$ However, from a pure psychological perspective, since the weak radical of mute roots became a quiescent consonant, its exact identity is far from being transparent to native speakers of Hebrew. Note that some root derivations contain the "missing" letter in their printed forms. But since this letter is perceived as a vowel letter, it appears to belong to the word-pattern. The aim of Experiment 2 was to examine whether the presentation of all three root-letters of mute roots as primes facilitates lexical decisions to targets derived from them. Subjects were therefore presented with the same targets of Experiment 1, except that the primes contained the elusive quiescent letter, in addition to the repeated two letters of the roots.

\section{Method}

Participants. The participants were 48 undergraduate students at the Hebrew University, all native speakers of Hebrew, who took part in the experiment for course credit or payment. None of the participants had taken part in Experiment 1.

\footnotetext{
${ }^{2}$ Although for some mute roots there are arguments regarding whether the quiescent letter is a "y" or a "w".
} 
TABLE 2A

Examples of the stimuli used in Experiment 2 in the identity, related, and control conditions

\begin{tabular}{|c|c|c|c|}
\hline & Identity & Related & Control \\
\hline Mask & \#\#\#\#\#\#\# & \#\#\#\#\#\#\# & \#\#\#\#\#\#\# \\
\hline \multirow[t]{4}{*}{ Prime } & $\begin{array}{l}\text { /hokara/ } \\
\text { (respect) }\end{array}$ & & \\
\hline & y.q.r (ר.ק.") & & \\
\hline & hwqrh & yqr & hqr \\
\hline & הוקרה & יקר & הקרו \\
\hline \multirow[t]{2}{*}{ Target } & hwqrh & hwqrh & hwqrh \\
\hline & הוקרה & הוקרה & הוקרה \\
\hline
\end{tabular}

Stimuli and design. The stimuli consisted of the same 48 target words which were used in Experiment 1. As in Experiment 1, the target words were paired with 48 primes to create three experimental conditions: in the identity condition, primes and targets were the same word. In the related condition, the primes consisted of the three formal letters that form the root, and the targets were the root derivations. Note that because Experiment 2 deals with mute roots, one of the letters of the root does not necessarily appear in the target word. In the control condition, the primes consisted of a sequence of three letters contained in the target, which were not the root letters. The number of possible word readings was 38 in the related condition and 17 in the control condition. An example of the stimuli used in the experiment is presented in Table $2 \mathrm{~A}$, the stimuli are presented in Appendix C. As with the word targets, the nonwords were also divided into three experimental conditions. The stimuli were divided into three lists. Each list contained 16 words and 16 nonwords in each of the three experimental conditions. The stimuli were rotated within the three conditions in each list in a Latin Square design.

Procedure and apparatus. The procedure and apparatus were identical to those in Experiment 1.

\section{Results and discussion}

Response times were averaged for correct responses in the three experimental conditions across participants and across items. The results are presented in Table 2B. Lexical decisions to targets were facilitated in the identity condition $(14 \mathrm{~ms})$ when the primes and the targets were the same word. The interesting results, however, concern lexical decisions to target words with morphologically related primes. In the related condition no facilitation whatsoever was obtained. 
TABLE 2B

Reaction Times (RTs, in ms) and per cent errors for lexical decision to target words and nonwords in the identity, related and control conditions of Experiment 2

\begin{tabular}{ccccccc}
\hline & Words & & & \multicolumn{3}{c}{ Nonwords } \\
\cline { 1 - 2 } \cline { 5 - 7 } Identity & Related & Control & & Identity & Related & Control \\
\hline 569 & 583 & 583 & & 638 & 647 & 642 \\
$5 \%$ & $7.2 \%$ & $8 \%$ & & $8.1 \%$ & $7.7 \%$ & $8.4 \%$ \\
$\mathbf{+ 1 4}$ & $\mathbf{+ 0}$ & & $\mathbf{+ 4}$ & $\mathbf{- 5}$ & \\
\hline
\end{tabular}

The results were subjected to a two-way ANOVA in which the prime condition was one factor and the word list was the other. The primecondition factor was significant in both the participants and the item analyses, $F_{1}(2,102)=6.78, M S E=529, p<.0017 ; F_{2}(2,90)=6.18, M S E$ $=653, p<.0031$, but this was due only to the faster latencies in the identity condition. The important result, however, was the identical latencies in the related and the control condition. The error analysis revealed a significant prime condition factor $F_{1}(2,102)=3.86, M S E=34$, $p<.024 ; F_{2}(2,90)=3.42, M S E=34, p<.037$. This was mainly due to fewer errors in the identity condition. The number of errors in the related and the control conditions did not differ significantly $\left(F_{1}\right.$ and $\left.F_{2}<1\right)$. The prime effect for nonwords was not significant for both participants and items. $F_{1}(2,102)=2.24, M S E=482, p<.112 ; F_{2}(2,90)=2.24, M S E=$ $575, p<.113$. No effect was found for errors to nonwords $\left(F_{1}\right.$ and $\left.F_{2}<1\right)$.

Similar to Experiment 1, planned comparisons were conducted to assess whether prime lexicality had any effect on response latencies. As in the previous experiment, lexical decision latencies to the targets did not differ significantly when the three-letter primes could be read as words or not, in both the related and the control conditions, $t(46)=0.7, p<.5 ; t(46)=0.7$, $p<.5$; respectively).

The results of Experiment 2 show that, unlike complete roots, the formal tri-consonantal root of mute roots does not facilitate the recognition of forms derived from it. One possible explanation to consider is that the identity priming effect obtained in the Experiment was relatively small (14 ms only), whereas a larger effect (32 ms) was obtained in Experiment 1. By this view, perhaps the priming in the related condition was partly eliminated given the overall small priming effects obtained in the experiment (variations in the size of the identity priming are not uncommon in masked priming experiments). However, from a theoretical perspective, the lack of morphological priming is not surprising. In order to establish any form of root representation, or, alternatively, in order to pick up on the statistical structure between form and meaning, the three consonants of the root need be transparent to the speaker. In the case of 
mute roots, they are not. If this interpretation is indeed correct, then we should note that the two repeated letters of mute roots were present in the priming stimuli, as they were in Experiment 1 . Thus, it seems that the mere presentation of the additional formal letter, which is missing in the derivations, was enough to eliminate the priming effect. We will refer to the implications of this finding in the General Discussion.

\section{EXPERIMENT 3}

In Experiment 3, the processing of defective roots was investigated. As described in the introduction, unlike mute roots, defective roots are characterised by an assimilation of one of the consonants of the root in certain derivations, whereas in other derivations all the letters and phonemes of the root are transparent. Readers of Hebrew are therefore exposed to the third consonant, although not to the same extent as they are with complete roots. The aim of Experiment 3 was to examine whether defective roots are processed by native readers as mute roots are. Thus, in Experiment 3 subjects were presented with primes consisting of the two letters of the defective root, which are repeated in all derivations. We examined whether the two repeated letters of defective roots facilitate lexical decisions to targets that are root derivations.

\section{Method}

Participants. The participants were 48 undergraduate students at the Hebrew University, all native speakers of Hebrew, who took part in the experiment for course credit or payment.

Stimuli and design. The stimuli consisted of 36 target words that were both verbal (past, singular, masculine) and nominal forms which were derived from defective roots. All the targets were words in the defective form, namely, the first letter of the root was opaque. Targets were three to six letters long and contained two or three syllables with five to seven phonemes. Their mean number of letters was 4.06 and their mean number of phonemes was 5.44. The target words were paired with 36 primes to create three experimental conditions, identity, related, and control. In the related condition, the primes consisted of the two letters of the root which are repeated across all the various derivations of the root, and the targets were the root derivations in their defective form. In the control condition, the primes consisted of a sequence of two letters contained in the target, which were not the two letters of the root. The number of possible word readings was 21 in the related condition and 16 in the control condition. An example of the stimuli used in the experiment is presented in Table $3 \mathrm{~A}$; the stimuli are presented in Appendix D. As with the word targets, the 
TABLE 3A

Examples of the stimuli used in Experiment 3 in the identity, related and control conditions

\begin{tabular}{|c|c|c|c|}
\hline & Identity & Related & Control \\
\hline Mask & \#\#\#\#\#\#\# & \#\#\#\#\#\#\# & \#\#\#\#\#\#\# \\
\hline \multirow[t]{3}{*}{ Prime } & $\begin{array}{l}\text { /mapolet/ } \\
\text { (landslide) } \\
\text { n.p.l (ל.9..) }\end{array}$ & & \\
\hline & mpwlt & $\mathrm{pl}$ & $\mathrm{pt}$ \\
\hline & מפולת & פל & פת \\
\hline \multirow[t]{2}{*}{ Target } & mpwlt & mpwlt & mpwlt \\
\hline & משולת & משולה & מסולת \\
\hline
\end{tabular}

nonwords were also divided into three experimental conditions. The stimuli were divided into three lists. Each list contained 12 words and 12 nonwords in each of the three experimental conditions. The stimuli were rotated within the three conditions in each list in a Latin square design.

Procedure and apparatus. The procedure and apparatus were identical to those in Experiment 1.

\section{Results and discussion}

Response times were averaged for correct responses in the three experimental conditions across participants and across items. The results are presented in Table 3B. Lexical decisions to targets were facilitated in the identity condition $(29 \mathrm{~ms})$ when the primes and the targets were the same word. The interesting result, however, is that, similar to Experiment 1 , there was a large priming effect in the related condition $(19 \mathrm{~ms})$.

The results were subjected to a two-way ANOVA in which the prime condition was one factor and the word list was the other. The primecondition factor was significant in both the participants and the item analyses, $F_{1}(2,90)=10.50, M S E=959, p<.001 ; F_{2}(2,66)=11.55, M S E=$ $643, p<.001$. Planned comparisons revealed that the difference between

TABLE 3B

Response times and per cent errors for lexical decision to target words and nonwords in the identity, related and control conditions of Experiment 3

\begin{tabular}{ccccccc}
\hline & Words & & & 3 & Nonwords \\
\cline { 1 - 2 } \cline { 5 - 6 } Identity & Related & Control & & Identity & Related & Control \\
\hline 601 & 611 & 630 & & 683 & 685 & 679 \\
$8.7 \%$ & $8.3 \%$ & $11.8 \%$ & & $13 \%$ & $12.3 \%$ & $12 \%$ \\
$\mathbf{+ 2 9}$ & $\mathbf{+ 1 9}$ & & $\mathbf{- 4}$ & $\mathbf{- 6}$ & \\
\hline
\end{tabular}


the related and the control conditions was significant for participants and for items, $F_{1}(1,45)=8.30, M S E=976, p<.006 ; F_{2}(1,33)=18.06, M S E=$ $421, p<.001$. The error analysis was not significant in the participants analysis but reached significance in the item analysis, $F_{1}(2,90)=2.13$, $M S E=82, p<.124 ; F_{2}(2,66)=3.25, M S E=40, p<.045$. The number of errors in the related and the control conditions differed significantly for items but nor for participants. $F_{1}(1,45)=3.59, M S E=80, p<.064 ; F_{2}(1$, $33)=7.68, M S E=28, p<.009$. The prime effect for nonwords was not significant for participants and items $\left(F_{1}\right.$ and $\left.F_{2}<1\right)$, nor was the effect for errors $\left(F_{1}\right.$ and $\left.F_{2}<1\right)$. As in the previous experiments, planned comparisons revealed that lexical decision latencies to the targets did not differ significantly when the two-letter primes could be read as words or not, in both the related and the control conditions, $t(34)=0.2, p<.8$; $t(34)=1.1, p<.3$; respectively.

In essence, the results of Experiment 3 replicate those of Experiment 1. Primes consisting of the two letters of a defective root which are repeated in all the root derivations facilitate lexical decision to the respective derivations. This outcome suggests again that a tri-consonantal structural constraint is not imposed on the root morpheme representation.

\section{EXPERIMENT 4}

The main difference between mute and defective roots concerns the quasiregular appearance of the third consonant. Thus, in defective roots one radical is assimilated into the following radical only in certain derivations, whereas for the rest of the derivations the three consonants of the defective root are entirely transparent. The aim of Experiment 4 was to examine whether the partial exposure to the assimilated radical in certain derivations is sufficient to establish a tri-consonantal representation for defective roots that is similar to that for complete and intact Hebrew roots. For this purpose, subjects were presented with the three root letters of defective roots as primes, while the targets consisted of root derivations which included the assimilated radical (i.e., targets appearing in their complete forms).

\section{Method}

Participants. The participants were 48 undergraduate students at the Hebrew University, all native speakers of Hebrew, who took part in the experiment for course credit or payment. None of the participants had taken part in Experiment 3.

Stimuli and design. The stimuli consisted of 36 target words that were both verbal and nominal forms, which were derived from the same defective roots employed in Experiment 3. All the targets in Experiment 4, 
TABLE 4A

Examples of the stimuli used in Experiment 4 in the identity, related and control conditions

\begin{tabular}{|c|c|c|c|}
\hline & Identity & Related & Control \\
\hline Mask & \#\#\#\#\#\#\# & \#\#\#\#\#\#\# & \#\#\#\#\#\#\# \\
\hline \multirow[t]{3}{*}{ Prime } & $\begin{array}{c}\text { /nefila/ } \\
\text { (fall) } \\
\text { n.p.l (ל.9. })\end{array}$ & & \\
\hline & npylh & npl & plh \\
\hline & גיפלה & נפל & פלה \\
\hline \multirow[t]{2}{*}{ Target } & npylh & npylh & npylh \\
\hline & גפילה & עפילה & גפילה \\
\hline
\end{tabular}

however, were derivations in which the three letters of the defective roots were transparent. Targets were four to six letters long, and contained two or three syllables with five to eight phonemes. Their mean number of letters was 4.64 and their mean number of phonemes was 5.92. The target words were paired with 36 primes to create three experimental conditions, identity, related, and control. In the related condition, the primes consisted of the three letters of the root and the targets were the root derivations in their complete form. In the control condition, the primes consisted of a sequence of three letters contained in the target which were not the three letters of the root. The number of possible word readings was 29 in the related condition and 11 in the control condition. An example of the stimuli used in the experiment is presented in Table 4A, the stimuli are presented in Appendix E. As with the word targets, the nonwords were also divided into three experimental conditions. The stimuli were divided into three lists. Each list contained 12 words and 12 nonwords in each of the three experimental conditions.

Procedure and apparatus. The procedure and apparatus were identical to those in the previous experiments.

\section{Results and discussion}

Response times were averaged for correct responses in the three experimental conditions across participants and across items. The results are presented in Table 4B. Lexical decisions to targets were facilitated in the identity condition $(22 \mathrm{~ms})$ when the primes and the targets were the same word. However, similar to the primes consisting of the two repeated letters, but in sharp contrast to the results of Experiment 2 with mute roots, there was a significant and robust priming effect in the related condition (17 ms). 
TABLE 4B

Response times and per cent errors for lexical decision to target words and nonwords in the identity, related and control conditions of Experiment 4

\begin{tabular}{ccccccc}
\hline & Words & & & \multicolumn{3}{c}{ Nonwords } \\
\cline { 1 - 2 } \cline { 5 - 6 } Identity & Related & Control & & Identity & Related & Control \\
\hline 618 & 623 & 640 & & 689 & 699 & 688 \\
$8.2 \%$ & $7.2 \%$ & $11.6 \%$ & & $8.9 \%$ & $10.8 \%$ & $6.6 \%$ \\
$\mathbf{+ 2 2}$ & $\mathbf{+ 1 7}$ & & $\mathbf{- 1}$ & $\mathbf{- 1 1}$ & \\
\hline
\end{tabular}

The results were subjected to a two-way ANOVA in which the prime condition was one factor and the word list was the other. The primecondition factor was significant for both participants and items, $F_{1}(2,108)$ $=5.94, M S E=1265, p<.0036 ; F_{2}(2,66)=5.72, M S E=1051, p<.005$. Planned comparisons revealed that the difference between the related and the control conditions was significant for both participants and items, $F_{1}(1$, $54)=6.50, M S E=1285, p<.014 ; F_{2}(1,33)=5.42, M S E=1215, p<.026$. The error analysis revealed a significant effect for participants and a significant effect for items. $F_{1}(2,108)=5.25, M S E=57, p<.007 ; F_{2}(2,66)$ $=4.13, M S E=46, p<.020$. The number of errors in the related the control conditions differed significantly, $F_{1}(1,54)=10.17, M S E=54, p<$ $.002 ; F_{2}(1,33)=8.19, M S E=42, p<.007$. RTs in the identity and the control conditions for nonwords were virtually identical. Once again, planned comparisons revealed that response latencies to the targets did not differ significantly when the three-letter primes could be read as words or not, in both the related and the control conditions, $t(34)=0.4, p<.7 ; t(34)$ $=1.4, p<.2$; respectively).

The conclusions from Experiment 4 are straightforward. Primes that include the variably missing letter of defective roots facilitate the recognition of targets that are defective-root derivations.

\section{EXPERIMENT 5}

Experiment 4 yielded one interesting outcome: similar to complete roots (Frost et al., 1997), the three consonants of defective roots produced significant root priming. These results, however, do not concur with the findings obtained with mute roots in Experiment 2. The possible difference between the two experiments is that the targets employed in Experiment 2 did not include the third consonantal letter which appeared in the priming stimulus, whereas the targets employed in Experiment 4 included the three letters of the defective roots. Thus, the overall orthographic similarity between primes and targets may have been larger for the defective roots than for the mute roots. The aim of Experiment 5 was to examine whether 
root priming can be obtained when the three letters of defective roots are presented as primes but the weak radical is missing in the target. Any priming effect obtained in this experimental manipulation will emphasise the morphological origin of the priming effect, and will reinforce the conclusion that defective roots have acquired a tri-consonantal representation for readers of Hebrew. For this purpose, participants were presented with target words, all defective root derivations, in which the weak radical was missing. The targets in the related condition were primed by the three letters of the defective roots. This introduced an additional orthographic dissimilarity relative to the manipulation employed in the previous experiment.

\section{Method}

Participants. The participants were 48 undergraduate students at the Hebrew University, all native speakers of Hebrew, who took part in the experiment for course credit or payment. None of the participants had taken part in Experiments 3 or 4.

Stimuli and design. The stimuli consisted of the same 36 target words as in experiment 3 with slight changes. Like Experiment 3, the target words appeared in their defective form (one letter of the root was missing). Targets were three to six letters long, and contained two or three syllables with five to seven phonemes. Their mean number of letters was 4.11 and their mean number of phonemes was 5.47. The target words were paired with 36 primes to create three experimental conditions: identity related, and control. In the related condition, the primes consisted of the three letters of the root, whereas the targets were the root derivations in their defective form. In the control condition, the primes consisted of complete roots that contained two letters of the defective roots, the letters which are repeated in all of the roots' derivations, in addition to another letter which did not belong to the root. This ensured complete orthographic similarity between the related and the control conditions. The number of possible word readings was 31 in the related condition and 33 in the control condition. An example of the stimuli used in the experiment is presented in Table 5A, the stimuli are presented in Appendix F. The stimuli were divided into three lists, each list contained 12 words and 12 nonwords in each of the three experimental conditions. The procedure and apparatus were identical to those in the previous experiments.

\section{Results and discussion}

Response times for correct responses were averaged in the three experimental conditions across participants and across items. The results 
TABLE 5A

Examples of the stimuli used in Experiment 5 in the identity, related and control conditions

\begin{tabular}{|c|c|c|c|}
\hline & Identity & Related & Control \\
\hline Mask & \#\#\#\#\#\#\# & \#\#\#\#\#\#\# & \#\#\#\#\#\#\# \\
\hline \multirow[t]{3}{*}{ Prime } & $\begin{array}{l}\text { /mapolet/ } \\
\text { (landslide) } \\
\text { n.p.l (ל.9) }\end{array}$ & & \\
\hline & mpwlt & $\mathrm{npl}$ & $\mathrm{kpl}$ \\
\hline & מלולת & ניל & 309 \\
\hline \multirow[t]{2}{*}{ Target } & mpwlt & mpwlt & mpwlt \\
\hline & משולת & מפולת & מסולת \\
\hline
\end{tabular}

are presented in Table 5B. Lexical decisions to targets were facilitated in the identity condition ( $35 \mathrm{~ms}$ ). The interesting result, however, is, that similar to Experiment 4, there was a significant priming effect in the related condition (19 $\mathrm{ms}$ ) even though not all the three consonants of the root were present in the targets.

The results were subjected to a two-way ANOVA in which the prime condition was one factor and the word list was the other. The prime condition factor was significant in both the participants and the item analysis, $F_{1}(2,90)=15.49, M S E=969, p<.001 ; F_{2}(2,66)=10.94, M S E=$ $866, p<.001$. Planned comparisons revealed that the difference between the related and the control conditions was significant for both participants and items. $F_{1}(1,45)=9.50, M S E=944, p<.004 ; F_{2}(1,33)=7.48, M S E=$ $756, p<.001$. The error analysis revealed a nonsignificant effect for both participants and items $\left(F_{1}\right.$ and $\left.F_{2}<1\right)$. The number of errors in the related and the control conditions did not differ significantly $\left(F_{1}\right.$ and $\left.F_{2}<1\right)$. The prime effect for nonwords revealed a significant effect for both participants and items. $F_{1}(2,90)=8.87, M S E=1057, p<.001 ; F_{2}(2,66)=5.93, M S E$ $=852, p<.005$. The error analysis of nonwords revealed a nonsignificant effect for both participants and items $F_{1}(2,90)=2.27, M S E=113, p<$ $.109 ; F_{2}(2,66)=2.92, M S E=66, p<.061{ }^{3}$ Since almost all primes had a word reading in both the related and the control condition, we did not assess the effect of lexicality.

The results of Experiment 5 clearly demonstrate the differences between mute and defective roots. Unlike Experiment 2, the three letters of defective roots facilitated the recognition of root derivations even though

\footnotetext{
${ }^{3}$ We have no explanation for the effect obtained for nonwords, since the printing obtained under masked presentation is considered a lexical effect. We can only report that such effects have sometimes been found and reported in our laboratory (e.g., Frost et al., 2000, Expt 3).
} 
TABLE 5B

Response times and per cent errors for lexical decision to target words and nonwords in the identity, related and control conditions of Experiment 5

\begin{tabular}{ccccccc}
\hline & Words & & & \multicolumn{3}{c}{ Nonwords } \\
\cline { 1 - 2 } \cline { 5 - 6 } Identity & Related & Control & & Identity & Related & Control \\
\hline 570 & 586 & 605 & & 634 & 653 & 662 \\
$9.2 \%$ & $10.1 \%$ & $11.1 \%$ & & $17.2 \%$ & $13.4 \%$ & $13 \%$ \\
$\mathbf{+ 3 5}$ & $\mathbf{+ 1 9}$ & & & $\mathbf{+ 2 8}$ & $\mathbf{+ 9}$ & \\
\hline
\end{tabular}

one of the letters of the root was missing in the target. From a representational perspective, the results of Experiment 5 together with Experiment 4 seem to suggest that defective roots have an allomorphic representation. The priming effects obtained with the two repeated letters of the root and with the full three letters are virtually identical.

\section{EXPERIMENT 6A AND 6B}

The priming effects obtained for both mute and defective roots suggest that the two repeated letters of the root are sufficient to induce morphological priming. The aim of Experiment $6 \mathrm{a}$ and $6 \mathrm{~b}$ was to investigate whether this finding extends to complete roots as well. None of the previous experiments investigating root priming with complete roots tested whether two root letters facilitate target recognition better than any other letters of the word. If all three root letters yield robust priming but any pair of root letters do not, it would implicate highly conjunctive, nonlinear processing in morphology that would place strong constraints on graded, distributed accounts. To avoid inferential problems related to statistical power, two sets of participants as well as two sets of items were tested in two independent experiments, $6 \mathrm{a}$ and $6 \mathrm{~b}$.

\section{Method}

Participants. The participants were 48 undergraduate students at the Hebrew University, all native speakers of Hebrew, who took part in the experiment for course credit or payment.

Stimuli and design. The stimuli consisted of 48 target words. All targets were derived from complete roots. Targets were four to six letters long, and contained two or three syllables with five to eight phonemes. Their mean number of letters was 4.92 and their mean number of phonemes was 6.19. The target words were paired with 48 primes to create three experimental conditions, identity, related, and control. In the related 
TABLE 6A

Examples of the stimuli used in Experiment 6 in the identity, related and control conditions

\begin{tabular}{|c|c|c|c|}
\hline & Identity & Related & Control \\
\hline Mask & \#\#\#\#\#\#\# & \#\#\#\#\#\#\# & \#\#\#\#\#\#\# \\
\hline \multirow[t]{3}{*}{ Prime } & $\begin{array}{l}\text { /maxberet/ } \\
\text { (notebook) } \\
\text { x.b.r (ר.ח. }\end{array}$ & & \\
\hline & mxbrt & $\mathrm{xr}$ & $\mathrm{mb}$ \\
\hline & עחפרת & זר & 3 \\
\hline \multirow[t]{2}{*}{ Target } & mxbrt & mxbrt & mxbrt \\
\hline & מחברת & מחברת & מחברת \\
\hline
\end{tabular}

condition, the primes consisted of two out of the three letters of the root. ${ }^{4}$ In the control condition, the primes consisted of a sequence of two letters contained in the target, which were not the two letters of the root. In both the related and the control conditions, half of the trials involved the disruption of the prime's sequence within the target, and half of the trials did not. The number of possible word readings was 34 in the related condition and 22 in the control condition. An example of the stimuli used in the experiment is presented in Table 6A; the stimuli are presented in Appendix G. Forty-eight target nonwords were employed and similar to the words, they included three experimental conditions. The stimuli were divided into three lists. Each list contained 16 words and 16 nonwords in each of the three experimental conditions. The stimuli were rotated within the three conditions in each list in a Latin Square design. Sixteen different participants were tested in each list, performing a lexical decision task. The procedure and apparatus were identical to the previous experiments.

\section{Results}

Response times for correct responses were averaged in the three experimental conditions across participants and across items. The results are presented in Table 6B. Lexical decisions to targets were facilitated in the identity condition $(26 \mathrm{~ms})$ when the primes and the targets were the same word. The important result, however, concerns lexical decisions in the related condition: only a small facilitation was obtained $(7 \mathrm{~ms})$.

The prime-condition factor was significant in both the participants and the item analyses, $F_{1}(2,90)=23.86, M S E=384, p<.001 ; F_{2}(2,90)=5.22$, $M S E=1979, p<.008$. Planned comparisons revealed that the difference

\footnotetext{
${ }^{4}$ One third of the primes were the first and second letters of the root, a third were the first and last letters of the root, and a third were the second and third phoneme of the root.
} 
TABLE 6B

Response times and per cent errors for lexical decision to target words and nonwords in the identity, related and control conditions of Experiment $6 \mathrm{a}$

\begin{tabular}{ccccccc}
\hline & Words & & & \multicolumn{3}{c}{ Nonwords } \\
\cline { 1 - 2 } \cline { 5 - 7 } Identity & Related & Control & & Identity & Related & Control \\
\hline 536 & 555 & 562 & & 606 & 604 & 613 \\
6 & 8.3 & 7.8 & & 5.2 & 7.1 & 5.9 \\
$\mathbf{+ 2 6}$ & $\mathbf{+ 7}$ & & $\mathbf{1}$ & $\mathbf{+ 9}$ & \\
\hline
\end{tabular}

between the related and the control conditions was not significant for both participants and items. $F_{1}(1,45)=2.89, M S E=374, p<.096 ; F_{2}<1$. The error analysis revealed a non-significant prime condition factor for both participants and items. $F_{1}(2,90)=1.94, M S E=38, p<.150 ; F_{2}<1$. The number of errors in both the related condition and the control condition did not differ significantly $\left(F_{1}\right.$ and $\left.F_{2}<1\right)$. The prime effect for nonwords revealed a nonsignificant effect for participants and for items. $F_{1}(2,90)=$ $2.96, M S E=392, p<.057 ; F_{2}(2,90)=2.22, M S E=752, p<.114$. No effect was found for errors to nonwords. $F_{1}(2,90)=1.94, M S E=25, p<$ .15; $F_{2}<1$. Similar to all previous experiments, planned comparisons revealed that response latencies to the targets did not differ significantly when the two-letter primes could be read as words or not, in both the related and the control conditions, $t(46)=0.6, p<.6$; $t(46)=1.5, p<.1$; respectively.

\section{EXPERIMENT 6B}

Since Experiment 6a presents a critical constraint on the distributed approach, the null-effect obtained in the experiment seems to offer nonconclusive evidence regarding the ability of two root letters to prime root derivations. This outcome may be due simply to a lack of power. The aim of Experiment $6 \mathrm{~b}$ was to allow an operational replication of Experiment $6 \mathrm{a}$. Thus, the design of the experiment was identical to that of Experiment $6 a$, while 48 different participants were tested with 48 novel stimuli, the stimuli are presented in Appendix $\mathrm{H}$.

\section{Results and discussion}

The results are presented in Table 6C. Lexical decisions to targets were facilitated in the identity condition $(25 \mathrm{~ms})$ when the primes and the targets were the same word. However, while considering the related condition, no priming was observed whatsoever. In fact, the related condition was slightly slower than the control condition $(-4 \mathrm{~ms})$.

ANOVA revealed that the prime-condition factor was significant in both the participants and the item analyses, $F_{1}(2,90)=29.25, M S E=398, p<$ 
TABLE 6C

Response times and per cent errors for lexical decision to target words and nonwords in the identity, related and control conditions of Experiment $6 \mathrm{~b}$

\begin{tabular}{ccccccc}
\hline & Words & & & \multicolumn{3}{c}{ Nonwords } \\
\cline { 1 - 2 } \cline { 5 - 6 } Identity & Related & Control & & Identity & Related & Control \\
\hline 547 & 576 & 572 & & 615 & 621 & 622 \\
5.6 & 8.3 & 7.9 & & 9.4 & 9.1 & 8.1 \\
$\mathbf{+ 2 5}$ & $\mathbf{- 4}$ & & $\mathbf{+ 7}$ & $\mathbf{+ 1}$ & \\
\hline
\end{tabular}

$.001 ; F_{2}(2,90)=8.63, M S E=1434, p<.001$. Planned comparisons revealed that the small inhibition observed in the related condition was not significant for both participants and items, $F_{1}$ and $F_{2}<1$. The error analysis revealed a non-significant prime condition factor for both participants and items. $F_{1}(2,90)=2.65, M S E=40, p<.076 ; F_{2}<1$. The prime effect for nonwords revealed a non-significant effect for participants and for items, $F_{1}(2,90)=1.49, M S E=361, p<.231 ; F_{2}<1$. No effect was found for errors as well $\left(F_{1}\right.$ and $\left.F_{2}<1\right)$. Planned comparisons revealed that response latencies to the targets did not differ significantly when the two-letter primes could be read as words or not, in both the related and the control conditions, $t(46)=0.4, p<.7 ; t(46)=0.6$, $p<.5$; respectively.

The striking result of Experiments $6 \mathrm{a}$ and $6 \mathrm{~b}$ is that two letters of a complete root do not facilitate complete root derivations. In other words, unlike the mute and defective roots respectively, two letters of complete roots cannot prime the roots' derivations. This outcome suggests that morphological priming is not a linear product of increasing orthographic overlap. We will discuss the implications of this finding in the following General Discussion.

\section{GENERAL DISCUSSION}

The present study examined the processing of mute and defective Hebrew roots. Our experiments were motivated to a large extent by the two contrasting views of morphological representation and processing: the traditional localist view, which holds that the processing of morphologically complex words involves parsing the input into explicit morphemes and activating discrete units corresponding to these morphemes, and the PDP approach which holds that morphological processing reflects the learned sensitivity of internal distributed representations to the statistical structure among surface forms of words and their meanings. Although certain general characteristics of these theories as applied to morphology can be used to derive contrasting predictions (localist theories typically 
treat the derivation of component morphemes as an all-or-none event, whereas PDP theories treat morphological relatedness as a matter of degree), distinguishing between localist and distributed theories of cognitive processes is notoriously difficult (see, e.g., Schwartz, Martin, Saffran, \& Gagnon, 1997). From this perspective, we assume that any given set of experiments may provide important constraints to any of the present approaches. Thus, our discussion of the results will focus on the implications to both the localist and the PDP theories.

From a representational perspective, the results of the present study provide novel data that need to be incorporated into our previous model of processing morphological information in Hebrew (Deutsch et al., 1998; Frost et al., 1997). According to this model, all words, whether nouns or verbs, which are derived from a given root, are linked to a shared morphological unit corresponding to the root. The Hebrew lexical system is regarded as consisting of multiple levels of representations; a level of lexical units (i.e., words) and a level of sub-word units of root morphemes. These two levels are interconnected, so that the root morpheme can be accessed via the lexical level from words containing that root or, alternatively, directly following a process of morphologically decomposing the orthographic structure. By this view, the recognition of printed words is often aided by access to their respective roots. Therefore, presenting the root information in a fast priming paradigm facilitates the recognition of the target derived from that root. Given the unique characteristic of Semitic morphologies, we suggested that Hebrew readers decompose a printed word into its morphemic constituents by using a general constraint that is structural in nature-mainly, that root morphemes are triconsonantal entities (Frost et al., 2000).

The results of Experiment 1 and 2, which manipulated mute roots, do not support this assumption. Our findings clearly demonstrated that the two letters of mute roots which are repeated in all derivations facilitated the recognition of targets derived from these roots. Thus, our findings seem to compel localist models of Hebrew to accommodate morphemic units that are bi-consonantal as well. Note, however, that this may have implications for any word-parsing algorithm for Hebrew. Since root letters are not necessarily contiguous, relinquishing the tri-consonantal constraint may result in too many degrees of freedom regarding the possible identity of the root letters, rendering decomposition slow and inefficient. The only possible solution for such a stalemate would be to draw a demarcation line between our theory of representation and our theory of morphological decomposition. This solution would lead us to suggest that although morphemic units can, in principle, be bi-consonantal, the fast process of morphological decomposition still uses a tri-consonantal constraint for parsing the printed word. Hence, the reported absence of verbal-pattern 
priming for weak roots (Frost et al., 2000) reflects a simple decomposition failure rather than an absence of root-morpheme units for mute roots. In a nutshell, the tri-consonantal parsing constraint would work for most Hebrew words, but not for words derived from weak roots.

The findings of the experiments manipulating defective roots provide additional potential complications for the representational view. These experiments demonstrate that targets derived from defective roots can be primed either by a bi-consonantal or by a tri-consonantal root unit. This finding leads us to suggest that defective roots have an allomorphic representation. Thus, both the three consonants of the root and the two consonants which are repeated in all root derivations are represented at the morphemic level, and both units mediate the recognition of defective roots. Admittedly, this view lacks parsimony but it does accommodate all findings reported in Hebrew in a coherent framework.

An alternative explanation for the effects obtained with primes consisting of the three root letters of defective roots considers these priming effects as reflecting lexical priming rather than root priming. Since all defective roots in unpointed print can be read as nouns or verbs inflected in simple past tense, it is possible that the priming effects in this experiment resulted from the interconnections of morphologically related words at the lexical level rather than from connections between rootmorpheme units and word units (see Frost et al., 1997; Experiment 3, for a discussion). On this view, defective roots, like mute roots, have only biconsonantal representations.

On the PDP approach, lexical representations are not stipulated in advance but are derived in the process of learning internal representations that mediate among the written and spoken forms of words and their meanings. These internal representations are initially biased toward picking up direct correlations among input and output features. As a result, the network tends to map similar inputs to similar outputs, supporting effective generalisation. However, for those aspects of the mappings for which lower-order correlations are insufficient, the internal representations are pressured to develop sensitivity to higher-order structure. For example, internal units might learn to respond to conjunctions of input features but not to the features in isolation, as in the classic exclusive-OR (XOR) problem. It is important to emphasise, though, that such non-linear sensitivity generally arises only when lowerlevel structure is absent or misleading.

These properties are directly relevant to understanding the implications of the PDP approach for morphological processing. Morphology is the lowest level of linguistic structure for which similarity in form is (partially) predictive of similarity in meaning; for individual morphemes, the relationship among form and meaning is essentially arbitrary. As a 
consequence, correlations among lower-level features like letters or phonemes and semantic features are largely absent, and there is strong pressure for internal representations to develop sensitivity to higher-order structure at roughly the level of morphemes. Note, however, that the system retains its bias toward relying on lower-level structure whenever possible, so that internal representations would be expected to reflect submorphological structure when it is, in fact, predictive of semantic properties.

The results of the first five experiments in the current series can be understood as natural implications of this theoretical perspective. Although not a full, three-consonant root in their own right, two of the consonants of a weak root are nonetheless reliably present in the surface forms derived from them and also have equivalent semantic correlations with meaning as complete roots. Thus, a PDP system would be expected to learn to represent two-consonant forms of weak roots much like standard roots, and exhibit priming to forms derived from them (Experiments 1 and 3).

The PDP account can also explain the observed difference among mute versus defective roots; namely, that full tri-consonantal forms of defective but not mute roots serve as effective morphological primes (Experiments 2,4 , and 5). This is because only for defective roots is the tri-consonantal form unambiguously available in the input. For mute roots, by contrast, the system has had little opportunity to learn the relationship between the triconsonantal form and the bi-consonantal form that actually occurs in derivations, even though, from a linguistic point of view, the former provides more complete evidence for the root morpheme.

The results of Experiment $6 \mathrm{a}$ and $6 \mathrm{~b}$, on the other hand, are less natural to account for within a PDP theory of Hebrew morphology, and thus place strong constraints on such a theory. These experiments showed that the priming from two-consonantal forms of weak roots does not generalise to complete roots; for the latter, two of three root consonants provided no greater priming of a derived form containing the root than did two nonroot letters. This pattern of results implies a very strong degree of nonlinearity in how the three consonants of standard roots are represented. Indeed, such fully conjunctive representations are, for all intents and purposes, functionally equivalent to localist representations of standard roots. On the PDP account, such conjunctive representations would be expected to develop through learning only when sensitivity to all lowerlevel structure is still insufficient to accomplish the mapping among forms and meanings. In fact, it is typically the case that any pair of consonants from a standard root also occur in many other roots. Thus, on its own, any given pair has little if any coherent implications for semantics. By contrast, although the two reliable consonants of a weak root may also occur in 
other roots, they do, on their own, have coherent semantic implications as a weak root.

In this way, the current findings provide evidence for sensitivity both to graded statistical structure and to "all-or-none" conjunctions in morphological processing. Although the PDP approach provides a theoretical basis for reconciling these properties, considerable work remains to develop an explicit implementation that accounts for all of the relevant findings. In addition, the approach must also account for existing empirical findings that suggest all-or-none, structure-dependent morphological parsing. In the current context, the clearest examples of such findings are the lack of word pattern priming for forms with weak roots and the reinstatement of such priming when the missing root letter is replaced by a random consonant (Frost et al., 2000). Such findings appear particularly problematic for PDP theories in that the presence or absence of morphological priming is tied, not to semantic or formal factors, but to the kinds of structural manipulations that would be expected to affect an all-or-none parsing mechanism.

However, Plaut and Frost (2001, in preparation) showed that a distributed connectionist network trained on an abstract version of Hebrew exhibited the same pattern of priming with weak roots, even though it lacked any explicit morphological parsing mechanism. Rather, over the course of learning, the system developed a high degree of sensitivity to the predominant tri-consonantal root structure of Hebrew, such that weak-root exceptions to this structure were represented very differently (and did not yield priming of words with the standard structure). Whether such a distributed approach can be extended to account for the more specific findings from the current set of studies remains to be demonstrated in future work.

\section{REFERENCES}

Baayen, H. (1991). Quantitative aspects of morphological productivity. In G. Booij \& J. Van Marle (Eds.), Yearbook of morphology (pp. 109-149). Dordrecht, the Netherlands: Kluwer Academic.

Berman, R. A. (1978). Modern Hebrew Structure. Tel Aviv, Israel: University Publishing Projects.

Blau, Y. (1971). Phonology and morphology. Tel Aviv, Israel: Hakibbutz Hameuchad Press. Butterworth, B. (1983). Lexical representation. In B. Butterworth (Ed.), Language production (Vol. 2, pp. 257-294). San Diego: Academic Press.

Burani, C., \& Laudanna, A. (1992). Units of representation of derived words in the lexicon. In I. R. Froat \& L. Katz (Eds.), Advances in psychology: Orthography, phonology, morphology and meaning (pp. 27-44). Amsterdam: Elsevier.

Caramazza, A., Laudanna, A., \& Romani, C. (1988). Lexical access and inflectional morphology. Cognition, 28, 207-332.

Dell, G. S., Schwartz, M. F., Martin, N., Saffran, E. M., \& Gagnon, D. A. (1997). Lexical access in normal and aphasic speakers. Psychological Review, 104, 801-838. 
Deutsch, A., Frost, R., \& Forster, K. I. (1998). Verbs and nouns are organized and accessed differently in the mental lexicon: Evidence from Hebrew. Journal of Experimental Psychology: Learning, Memory and Cognition, 24, 1238-1255.

Frauenfelder, U. H., \& Schreuder, R. (1991). Constraining psycholinguistic models of morphological processing and representation: The role of productivity. In G. Booij \& J. Van Marle (Eds.), Yearbook of morphology (pp. 165-183). Dordrecht, the Netherlands: Kluwer Academic.

Forster, K. I. (1987) Form priming with masked primes: The best match hypothesis. In M. Coltheart (Ed.), Attention and performance: XII. The psychology of reading (pp. 127-140). Hove, UK: Lawrence Erlbaum Associates Ltd.

Forster, K. I., \& Davis, C. (1984). Repetition priming and frequency attenuation in lexical access. Journal of Experimental Psychology: Learning, Memory, and Cognition, 10, 680-698.

Forster, K. I., Davis, C., Schocknecht, C., \& Carter, R. (1987). Masked priming with graphemically related forms: Repetition or partial activation? Quarterly Journal of Experimental Psychology, 39A, 211-251.

Frost, R., Deutsch, A., Gilboa, O., Tannenbaum, M., \& Marslen-Wilson, W. (2000). Morphological priming: Dissociation of phonological, semantic and morphological factors. Memory and Cognition, 28, 1277-1288.

Frost, R., Deutsch, A., \& Forster, K. I. (2000). Decomposing morphologically complex words in a nonlinear morphology. Journal of Experimental Psychology: Learning, Memory and Cognition, 36, 751-765.

Frost, R., Forster, K. I., \& Deutsch, A. (1997). What can we learn from the morphology of Hebrew? A masked-priming investigation of morphological representation. Journal of Experimental Psychology: Learning, Memory and Cognition, 23, 829-856.

Henderson, L., Wallis, J., \& Knight, K. (1984). Morphemic structure and lexical access. In H. Bouma \& D. Bouwhuis (Eds.), Attention and Performance X: Control of language process (pp. 211-226). Hove, UK: Lawrence Erlbaum Associates Ltd.

Laudanna, A., Burani, C., \& Cermele, A. (1994). Prefixes as processing units. Language and Cognitive Processes, 9, 295-316.

Marcus, G. F., Brinkmann, U., Clahsen, H., Weise, R., \& Pinker, S. (1995). German inflection: The exception that proves the rule. Cognitive Psychology, 29, 189-256.

Marslen-Wilson, W., Tyler, L. K., Waksler, R., \& Older, L. (1994). Morphology and meaning in English mental lexicon. Psychological Review, 101, 3-33.

Plaut, D. C., \& Frost, R. (2001). Does morphological structure in Hebrew reduce to surface structure? Paper presented at the 42nd annual meeting of the Psychonomic Society: Orlando, November 2001.

Plaut, D. C., \& Gonnerman, L. M. (2000). Are non-semantic morphological effects incompatible with a distributed connectionist approach to lexical processing? Language and Cognitive Processes, 15(4/5), 445-485.

Rueckl, J. G., Mikolinski, M., Raveh, M., Miner, C. S., \& Mars, F. (1997). Morphological priming, fragment completion and connectionist networks. Journal of Memory and Language, 36, 382-405.

Schreuder, R., \& Baayen, R. H. (1995). Modeling morphological processing. In L. B. Feldman (Ed.), Morphological aspects of language processing (pp. 131-154). Hillsdale, NJ: Lawrence Erlbaum Associates Inc.

Seidenberg, M. S. (1987). Sublexical structures in visual words recognition: access units or orthographic redundancy? In M. Coltheart (Ed.), Attention and performance XII: The psychology of reading (pp. 244-263). Hove, UK: Lawrence Erlbaum Associates Ltd.

Taft, M. (1994). Interactive activation as a framework for understanding morphological processing. Language and Cognitive Processes, 9, 271-294. 
APPENDIX A

The Hebrew Alphabet

\begin{tabular}{|c|c|c|}
\hline $\begin{array}{c}\text { Hebrew } \\
\text { Print }\end{array}$ & $\begin{array}{l}\text { Orthographic } \\
\text { Transcription }\end{array}$ & $\begin{array}{c}\text { Phonetic } \\
\text { Transcription }\end{array}$ \\
\hline$\kappa$ & $?$ & $?$ \\
\hline 2 & $b$ & $b / v$ \\
\hline$\lambda$ & $g$ & $\mathrm{~g}$ \\
\hline$T$ & $d$ & $d$ \\
\hline ה & $\mathrm{h}$ & $\mathrm{h}$ \\
\hline 1 & $w$ & $o / u / v$ \\
\hline$T$ & $z$ & z \\
\hline$n$ & $x$ & $x$ \\
\hline $\mathbf{v}$ & $\theta$ & $t$ \\
\hline ' & $y$ & $i / y$ \\
\hline 3 & k & $k / x$ \\
\hline${ }^{a} 7$ & $\mathrm{~K}$ & $x$ \\
\hline$ל$ & 1 & 1 \\
\hline$n$ & $\mathrm{~m}$ & $m$ \\
\hline${ }^{a} \mathrm{D}$ & $M$ & $\mathrm{~m}$ \\
\hline J & $\mathrm{n}$ & $\mathrm{n}$ \\
\hline${ }^{a}$ & $\mathbf{N}$ & $\mathrm{n}$ \\
\hline 0 & $\mathrm{~S}$ & $\mathrm{~s}$ \\
\hline ע & $\varsigma$ & 7 \\
\hline 9 & $p$ & $p / f$ \\
\hline${ }^{a} \eta$ & $P$ & f \\
\hline$y$ & $\mathrm{c}$ & $\underline{t s}$ \\
\hline${ }^{a} \gamma$ & $\mathrm{C}$ & $\overline{\mathrm{t} s}$ \\
\hline$p$ & $q$ & $\mathrm{k}$ \\
\hline 7 & $r$ & $r$ \\
\hline ש & $s$ & $\mathrm{~s} / \underline{\underline{\mathrm{sh}}}$ \\
\hline$\Omega$ & $\mathrm{t}$ & $t$ \\
\hline
\end{tabular}

${ }^{\mathrm{a}}$ The letters $\mathrm{k}, \mathrm{m}, \mathrm{n}, \mathrm{p}$, and $\mathrm{c}$ have different orthographic forms when they appear at the end of the word. 
APPENDIX B

Stimuli used in Experiment 1

\begin{tabular}{|c|c|c|c|c|c|c|}
\hline \multicolumn{3}{|c|}{ Target } & \multicolumn{2}{|c|}{$\begin{array}{l}\text { Morphological } \\
\text { Prime }\end{array}$} & \multicolumn{2}{|c|}{ Control } \\
\hline Word & $\begin{array}{l}\text { Ortho. } \\
\text { Trans. }\end{array}$ & $\begin{array}{c}\text { Phonetic } \\
\text { Trans. }\end{array}$ & Letters & $\begin{array}{l}\text { Ortho. } \\
\text { Trans. }\end{array}$ & Letters & $\begin{array}{l}\text { Ortho. } \\
\text { Trans. }\end{array}$ \\
\hline תאורה & trworh & /te?ural & אר" & $\mathrm{rr}$ & אה & Ph \\
\hline הוקרהה & hwqrh & /hokara/ & קר & $q r$ & הק & hq \\
\hline תוצאה & twc?h & /totsa?a/ & צא & $\mathrm{c} ?$ & תת & t? \\
\hline ריצה & rich & /riț̦a/ & רา & $\mathrm{rc}$ & צה & ch \\
\hline תולדה & twidh & /tolada/ & לד & Id & תל & $\mathrm{t} \mid$ \\
\hline הורדה & hwrdh & /horada/ & $n$ & rd & הר & hr \\
\hline תמותה & tmwth & /tmuta/ & מת & $\mathrm{mt}$ & תה & th \\
\hline תודעה & twdsh & /toda?al & ד & $d s$ & דה & dh \\
\hline מועצה & mwsch & /moratsal & $צ y$ & $\varsigma \mathrm{c}$ & מע & ms \\
\hline תורשה & twrsh & torashal & ש & rs & רה & ith \\
\hline מושבה & mwsbh & /moshava/ & שבב & sb & וש & ws \\
\hline תקומה & tqwmh & /tkumal & קמ & $q m$ & ומ & wm \\
\hline תגלית & tglit & /taglit/ & גל & gl & לת & it \\
\hline תבונה & tbwnh & trunal & בנ & bn & תנ & $\operatorname{tn}$ \\
\hline תזונה & tzwnh & /tzunal & זנ & $\mathrm{zn}$ & נה & $\mathrm{nh}$ \\
\hline olun & mEwS & /matos/ & ou & es & מו & $\mathrm{mw}$ \\
\hline תלונה & twah & /tlunal & לנ & $\ln$ & Iת & tw \\
\hline הויבלה & hwblh & hovala/ & בל & bl & הל & hl \\
\hline תבואה & tbw?h & Itvu?al & בא & b? & בה & bh \\
\hline תמורה & tmwrh & /tmural & מר & $\mathrm{mr}$ & מה & $\mathrm{mh}$ \\
\hline מווסד & mwSd & $/ \mathrm{mosad} /$ & TO & Sd & on & $\mathrm{ms}$ \\
\hline הועלות & twclt & /to?elet & $y$ & ऽا & עת & $s$ \\
\hline תקופה & tqwph & /tkufa/ & קפ & $q p$ & קה & qh \\
\hline מוצג & mwcg & /mutsag/ & $\lambda Y$ & $\mathrm{cg}$ & YI & wc \\
\hline בושה & bwsh & /busha/ & ט & bs & שה & sh \\
\hline מוצצר & $\mathrm{mwcr}$ & /mutsarl & צר & $\mathrm{Cr}$ & מו & $\mathrm{mw}$ \\
\hline מועד & mwsd & /moied/ & עד & so & מע & $\mathrm{m} \zeta$ \\
\hline תככונה & tkwnh & Itxunal & כנ & $\mathrm{kn}$ & תכ & $\mathrm{tk}$ \\
\hline הוכחה & hwkxh & /hoxaxal & כח & $k x$ & כה & $\mathrm{kh}$ \\
\hline חעופה & tรwph & /te?ufal & עפ & $\mathrm{sp}$ & פה & ph \\
\hline נסיעה & nSych & /nesi?a/ & wo & $\mathrm{S}_{\zeta}$ & ענ & $\zeta n$ \\
\hline ריקנות & ryqnwt & /rekanot & רק & rq & נק & $\mathrm{nq}$ \\
\hline กפดเת & twSpt & /tosefet/ & no & $\mathrm{Sp}$ & פת & $p t$ \\
\hline הוזלה & hwzlh & /hozala/ & זל & 21 & לה & th \\
\hline מוצב & mwcb & /mutsavi & צב & $c b$ & מב & $\mathrm{mb}$ \\
\hline תנוחה & tnwxh & thuxal & נח & $n x$ & ת & tx \\
\hline הפוגהה & hpwgh & /hafuga/ & פג & $\mathrm{pg}$ & 19 & pw \\
\hline מצוף & mcwP & /matsof & צפ & $c p$ & IY & $\mathrm{CW}$ \\
\hline תבוסה & tbwSh & /tvusa/ & בם & bs & on & ts \\
\hline מוקש & mwqs & /mokesh/ & ק & qs & וק & $w q$ \\
\hline מוצק & mwcq & /mutsak & צק & $\mathrm{cq}$ & מצ & $\mathrm{mc}$ \\
\hline מחוגה & mxwgh & $/ \mathrm{m} \times 0 \mathrm{ga} /$ & ג & $\mathrm{xg}$ & מג & $\mathrm{mg}$ \\
\hline מחצית & mxcit & /maxatsit/ & חצ & $x c$ & צת & ct \\
\hline מכולה & mkwlh & Imxolal' & כל & $\mathrm{kJ}$ & מל & $\mathrm{ml}$ \\
\hline תופעה & twpsh & /tofa?a/ & פעי & PS & עה & sh \\
\hline מותר & mwtr & /mutarl & תר & $\operatorname{tr}$ & ור & $w r$ \\
\hline מוקד & mwqd & /moked/ & קד & qd & m & $\mathrm{mw}$ \\
\hline מוזר & $m w z r$ & /muzar/ & זר & $2 r$ & מז & $\mathrm{mz}$ \\
\hline
\end{tabular}


APPENDIX C

Stimuli used in Experiment 2

\begin{tabular}{|c|c|c|c|c|c|c|}
\hline \multicolumn{3}{|c|}{ Target } & \multicolumn{2}{|c|}{$\begin{array}{l}\text { Morphological } \\
\text { Prime }\end{array}$} & \multicolumn{2}{|c|}{ Control } \\
\hline Word & $\begin{array}{l}\text { Ortho. } \\
\text { Trans. }\end{array}$ & $\begin{array}{c}\text { Phonetic } \\
\text { Trans. }\end{array}$ & Letters & $\begin{array}{l}\text { Ortho. } \\
\text { Trans. }\end{array}$ & Letters & $\begin{array}{l}\text { Ortho. } \\
\text { Trans. }\end{array}$ \\
\hline הארה & h?rh & /he?aral & אור & $7 w r$ & ארה & Prh \\
\hline הוקרה & hwqrh & /hokara/ & יקר & yqr & הקר & hqr \\
\hline תוצאה & twe?h & /totsa?a/ & NY' & yc7 & צאה & crh \\
\hline מריץ & mryc & $/$ merits $/$ & צו & rwc & מרצ & mrc \\
\hline תולדה & widh & /holada/ & ילד & yld & לדה & Idh \\
\hline הורדה & hwrdh & /horada/ & $T^{\prime}$ & yrd & רדה & rdh \\
\hline המתה & hmth & /hamata/ & מות & mut & התה & hth \\
\hline תודעה & twd $\zeta h$ & toda?a/ & $\boldsymbol{L} \mathbf{T}$ & yds & ודע & wds \\
\hline מועצה & mwsch & /mo'atsal & sy" & yçc & מעצ & m̧̧c \\
\hline תורשה & twrsh & torashal & ירש & yrs & רשה & rsh \\
\hline מושבהה & mwsbh & /moshava/ & "שע" & ysb & משב & mst \\
\hline הקמה & hqmh & thakamal & קומ & qwm & המה & $\mathrm{hmh}$ \\
\hline תגלית & tglyt & /taglit/ & גלה & glh & גלת & glt \\
\hline תבונה & tbwnh & /tvunal & בינ & byn & בנה & bnh \\
\hline הזנה & hznh & /hazana/ & זונ & zwn & הזה & hzh \\
\hline טיסן & $\theta y S N$ & /tisan. & 010 & Ows & Jo' & ySn \\
\hline לינה & lynh & flinal & לונ & Iwn & ינה & $y n h$ \\
\hline הובלה & hwblh & /hovala/ & יבל & $y b 1$ & בלה & blh \\
\hline לקנות & lqnwt & /liknov & קנה & quh & לנת & $\ln t$ \\
\hline ממיר & mimyr & /memir/ & מור & mwr & ממי & mmy \\
\hline מוסד & mwSd & $/$ mosad/ & $70 '$ & $y S d$ & מום & mws \\
\hline תועלת & twclt & toielet & יעל & $y \varsigma 1$ & תעל & ţ) \\
\hline ערנות & çrnwt & Reranut & עור & $5 w r$ & רנו & rnw \\
\hline אצנגה & towgh & /tetsuga/ & יצג & ycg & תוג & twg \\
\hline ביישן & byysN & /bayshan' & בוש & bws & בשנ & bsn \\
\hline מוצר & mwer & /mutsar/ & יצר & yer & מצר & $\mathrm{mcr}$ \\
\hline מועד & mwsd & $/$ moied $/$ & עי & $y \varsigma d$ & מעד & $\mathrm{m} \zeta \mathrm{d}$ \\
\hline הצבהה & ncbh & /hatsava/ & ' & ycb & צבה & $\mathrm{cbh}$ \\
\hline הוכחה & hwkxhs & /hoxaxal & ינח & $y k x$ & הכח & hkx \\
\hline עפיפון & spypwN & lafifonl & פIע & swp & עפנ & ૬pn \\
\hline שייטֶת & syyet & Shnayetev & שוט & swo & תטי & yet \\
\hline שיחון & syxwN & /sixon/ & שוח & $s w x$ & חונ & xwn \\
\hline nsoln & twSpt & tosefev & 201 & $y S p$ & תוס & tws \\
\hline הוזלה & hwzlh & /hozala/ & $4 \mathrm{~T}$ & $z w 1$ & זלה & zlh \\
\hline מוצב & mwcb & /mulșav/ & יצב & ycb & מוב & mwb \\
\hline מונח & $\operatorname{mwn} x$ & Imunax & נונ & $n w x$ & מנח & $m n x$ \\
\hline דירה & dyrh & /dira/ & דור & $d w r$ & דיה & dyh \\
\hline מוצף & mwcP & /mutsafi & צופ & cwp & וצפ & $w c p$ \\
\hline מובס & mwbs & ImuvasI & בוס & bwS & מבס & mbs \\
\hline מוקש & mwqs & /mokesh/ & יקש & yqs & מקש & mqs \\
\hline מוצק & mwcq & /mulsak/ & יצ' & ycq & מוק & $\mathrm{mwq}$ \\
\hline חייגן & xyygN & /xaygan/ & חוג & $x w g$ & חגנ & $\operatorname{xgn}$ \\
\hline חצות & $x c w t$ & Ixatsot & חצה & $x c h$ & צות & cwt \\
\hline הכיל & hkyl & Thexil/ & כול & $k w 1$ & הני & hky \\
\hline תופעה & twpch & Itofa?a/ & ys & yp & פעה & psh \\
\hline השבה & hsbh & /hashava/ & שוב & swb & הבה & hboh \\
\hline מוקד & mwqd & /moked/ & יקד & yqd & מוד & mwd \\
\hline לסטות & ISOwt & /istot & סטה & Soh & ת10 & Swt \\
\hline
\end{tabular}




\section{APPENDIX D}

Stimuli used in Experiment 3

\begin{tabular}{|c|c|c|c|c|c|c|}
\hline \multicolumn{3}{|c|}{ Target } & \multicolumn{2}{|c|}{$\begin{array}{c}\text { Morphological } \\
\text { Prime }\end{array}$} & \multicolumn{2}{|c|}{ Control } \\
\hline Word & $\begin{array}{l}\text { Ortho. } \\
\text { Trans. }\end{array}$ & $\begin{array}{c}\text { Phonetic } \\
\text { Trans. }\end{array}$ & Letters & $\begin{array}{l}\text { Ortho. } \\
\text { Trans. }\end{array}$ & Letters & $\begin{array}{l}\text { Ortho. } \\
\text { Trans. }\end{array}$ \\
\hline מתיד & mtyz & /matiz/ & ז & $t z$ & מד & $\mathrm{mz}$ \\
\hline הגיע & hgys & /higi?al & גע & gs & גי & gy \\
\hline מושק & mwsq & /mushak/ & שק & sq & מק & $\mathrm{mq}$ \\
\hline הקיז & hqyz & /hikiz/ & קז & $q z$ & r & $y z$ \\
\hline החיקי & hitya & /hitik/ & תק & tq & הת & ht \\
\hline הכיש & hkys & /hikish/ & כש & ks & יש & ys \\
\hline השיר & hsyr & Ihishirl & שר & $\mathrm{sr}$ & הש & hs \\
\hline הקייש & hqys & /hikish & קש & qs & קי & qy \\
\hline הד'ף & hdyP & /hidif/ & דפ & $d p$ & הפ & hp \\
\hline הציל & heyl & /hitsilil & צל & $\mathrm{cl}$ & הצ & he \\
\hline מביט & mby $\theta$ & /mabit/ & בט & $b \theta$ & מט & $m \theta$ \\
\hline ריזיל & hzyl & /hizil/ & זל & $z \mid$ & הל & $\mathrm{hl}$ \\
\hline הטיג & hSyg & /hisig/ & 20 & $5 g$ & הג & hg \\
\hline הגיד & hgyd & /higid/ & גדי & $\mathrm{gd}$ & הד & hd \\
\hline השיל & hsyl & /hishill & של & sl & יל & yl \\
\hline החיר & htyr & /hitin/ & תר & $\mathrm{tr}$ & הר & $\mathrm{hr}$ \\
\hline השיא & hsy? & /hisi?] & שא & s? & ינשי & sy \\
\hline הדיר & hodyr & /hidir/ & דר & $\mathrm{dr}$ & די & $d y$ \\
\hline מרכת & mtkt & /matexet & on & tk & n & kt \\
\hline מגבת & mgbt & /magevet & גב & $g b$ & מב & $\mathrm{mb}$ \\
\hline מפוחית & mpwxyt & /mapuxit/ & פ & $p x$ & מו & $\mathrm{mw}$ \\
\hline הסעה & hsçh & /hasa?a/ & עo & $S_{5}$ & סה & Sh \\
\hline משיר & msyr & /mashir/ & שר & sr & מר & $\mathrm{mr}$ \\
\hline היכרות & hykrwt & /hekerut/ & כר & $\mathrm{kr}$ & רו & $\mathrm{rw}$ \\
\hline מסוק & mswq & /masok/ & po & $\mathrm{Sq}$ & on & $\mathrm{ms}$ \\
\hline הרחה & $h d x h$ & /hadaxa/ & דח & $d x$ & הח & $h x$ \\
\hline מצור & mowr & /matsor $/$ & צר & $\mathrm{cr}$ & צו & $\mathrm{cw}$ \\
\hline מתנה & mtnh & Imatana/ & תננ & tn & מת & $\mathrm{mt}$ \\
\hline מטע & $m \theta \xi$ & imatar & טע & $\theta S$ & מע & $m s$ \\
\hline משב & $\mathrm{msb}$ & Imashavl & שב & sb & מש & $\mathrm{ms}$ \\
\hline הבעה & hbçh & /haba?a/ & בעل & bs & הב & $\mathrm{hb}$ \\
\hline מפץ & $\mathrm{mpC}$ & /mapats / & פצ & $\mathrm{pc}$ & מצ & $m c$ \\
\hline הסחה & $h S \times h$ & /hasaxa/ & no & $\$ x$ & חה & $x h$ \\
\hline מזיק & mzyq & /mazik/ & זק & $\mathrm{zq}$ & $n$ & my \\
\hline הגשה & hgsh & /hagashar & שג & gs & שה & $\mathrm{sh}$ \\
\hline
\end{tabular}


APPENDIX E

Stimuli used in Experiment 4

\begin{tabular}{|c|c|c|c|c|c|c|}
\hline \multicolumn{3}{|c|}{ Target } & \multicolumn{2}{|c|}{$\begin{array}{c}\text { Morphological } \\
\text { Prime }\end{array}$} & \multicolumn{2}{|c|}{ Control } \\
\hline Word & $\begin{array}{l}\text { Ortho. } \\
\text { Trans. }\end{array}$ & $\begin{array}{c}\text { Phonetic } \\
\text { Trans. }\end{array}$ & Letters & $\begin{array}{l}\text { Ortho. } \\
\text { Trans. }\end{array}$ & Letters & $\begin{array}{l}\text { Ortho. } \\
\text { Trans. }\end{array}$ \\
\hline 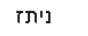 & nytz & Initaz/ & נתז & $\mathrm{ntz}$ & Ti & nwz \\
\hline נוגע & nwgs & /noge?a/ & נגעע & ngs & וגנע & wgs \\
\hline התנשק & htnsq & /hitnashek/ & נשק & nsq & תנק & tnq \\
\hline ניקז & nyqz & Inikez' & נקז & $n q z$ & ניק & nyq \\
\hline נוחק & nwtq & /nutak/ & נתקי & ntq & ותק & wtq \\
\hline מנקר & mnqr & /menaker/ & נקר & nqr & מנק & $\mathrm{mng}$ \\
\hline נושר & nwsr & /nosherl & נשר & nsr & ושר & wsr \\
\hline מתנקֶש & minqs & Imitnakesh/ & נקש & nqs & מקש & mas \\
\hline נודף & nwdP & Inodef/ & נדפ & ndp & ודפ & $w d p$ \\
\hline הצחל & htnel & /hitnatsel/ & נצל & $\mathrm{ncl}$ & תנצ & tnc \\
\hline נובט & nwbe & Inovet & נבט & $\mathrm{nb \theta}$ & ובט & $w b \theta$ \\
\hline נוזל & nwzl & /nozel/ & נזל & $\mathrm{nzl}$ & וזל & $w z l$ \\
\hline נסוג & nswg & Inasogl & 201 & $\Pi \mathrm{ng}$ & $\lambda 10$ & Swg \\
\hline הרנוגד & htngd & /hitnaged/ & נגד & ngd & תגד ר & $\operatorname{tgd}$ \\
\hline נושל & nwsl & Inusthall & נשל & nsl & ושל & wsl \\
\hline מנותר & mntr & Imenater & נתר & ntr & מתר & $\mathrm{mtr}$ \\
\hline התנשא & htns? & /hitnase/ & נשיא & ns? & השא & hs? \\
\hline נודר & $n w d r$ & Inoder/ & נדר & ndr & ודר & $w d r$ \\
\hline נתיך & ntyk & /natix/ & נתנכ - כ & ntk & תיכ & tyk \\
\hline נפילה & npylh & /nefila/ & נפל & $\mathrm{npl}$ & פלה & plh \\
\hline ניגוב & nygwb & /niguv/ & נגב & $\mathrm{ngb}$ & יגב & ygb \\
\hline נפיחות & npyxwt & /nefixut/ & נפח & $n p x$ & פוחת - = & pxt \\
\hline נoיעה & nSych & /nesiral & yos & $n S \zeta$ & העo & $S c h$ \\
\hline נשנורת & nswrt & Ineshoret/ & נשר & nsr & שרา & $\mathrm{sit}$ \\
\hline נוכרי & nwkry & /noxri/ & נכר & nkr & כרי & kry \\
\hline נסיקה & nsygh & /nesika/ & pos & $\mathrm{nSq}$ & ה⿻ุ & Sqh \\
\hline נידח & $n y d x$ & /nidax/ & נדח & $n d x$ & ניד & nyd \\
\hline ניצרה & nyarh & /nitsra/ & 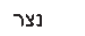 & ncr & ניה & nyh \\
\hline נתין & ntyN & /natin/ & נתננ & ntn & חינ & tyn \\
\hline נטיעה & nөych & Ineti?al & עou & $n \oplus 5$ & טיע & $\theta y \zeta$ \\
\hline נשיבה & nsybh & Ineshival & נשב & $n s b$ & שיב & syb \\
\hline נביעה & nbyç & Inevi?al & נבע & $\mathrm{nbs}$ & בעה & bsh \\
\hline מנופץ & mnwpC & /menupats & נפצנ & прс & צII & wpc \\
\hline נחוסחה & nwSxh & Inusxal & nou & $n S x$ & nol & wSh \\
\hline נזיקין & nzyqyN & Inezikin: & נזק & nzq & נקנ & nqn \\
\hline נג'שות & ngyswt & Inegishut & נגש & ngs & גשת & gst \\
\hline
\end{tabular}


APPENDIX F

Stimuli used in Experiment 5

\begin{tabular}{|c|c|c|c|c|c|c|}
\hline \multicolumn{3}{|c|}{ Target } & \multicolumn{2}{|c|}{$\begin{array}{c}\text { Morphological } \\
\text { Prime }\end{array}$} & \multicolumn{2}{|c|}{ Control } \\
\hline Word & $\begin{array}{l}\text { Ortho. } \\
\text { Trans. }\end{array}$ & $\begin{array}{c}\text { Phonetic } \\
\text { Trans. }\end{array}$ & Letters & $\begin{array}{l}\text { Ortho. } \\
\text { Trans. }\end{array}$ & Letters & $\begin{array}{l}\text { Ortho. } \\
\text { Trans. }\end{array}$ \\
\hline מתיז & mtyz & Imatizl & נחז & $n t z$ & תעז & $t \zeta z$ \\
\hline הגיע & hgys & Ihigi?al & נעג & ngs & רגעו & rgs \\
\hline מושק & mwsq & /mushak/ & נשק & nsq & קשח & $x s q$ \\
\hline הקיז & hqyz & /hikiz/ & נקז & nqz & קזז & $q z z$ \\
\hline התיק & htyq & /hitikJ & נתק & ntq & תקנ & $\operatorname{tqn}$ \\
\hline הכיש & mkys & /hikish/ & נכש & nks & רכש & rks \\
\hline השיר & hsyr & Thishirl & נשר & $\mathrm{nsr}$ & פשר & psr $r$ \\
\hline הקיש & hays & thikish/ & נקש & nqs & קשר & $q s r$ \\
\hline הדיף & hdyP & /hidif/ & נדפ & ndp & גדפ & gdp \\
\hline הציל & hcyl & /hitsil/ & נצל & $n c l$ & אצל & $\mathrm{Pcl}$ \\
\hline מביט & mbye & Imabit & נבט & $\mathrm{nb} \theta$ & חבט & $x b \theta$ \\
\hline הזיל & hzyl & /hizil/ & נזל & $n z l$ & אזול & Pzl \\
\hline הם'ג & hSyg & /hisig/ & 201 & $n S g$ & סגר & Sgr \\
\hline הגיד & hgyd & /higid/ & נגד & ngd & בגד & bgd \\
\hline משיל & msyl & /mashil/ & נשל & $n s \mid$ & כשל & ks! \\
\hline התיר & htyr & /hitir/ & נת ר & ntr & בתר & btr \\
\hline השיא & hsy? & /hisi?l & נשא & ns? & שאנ & sigg \\
\hline הדיר & hdyr & /hidir/ & נדר & $n d r$ & גדר & gdr \\
\hline מתכת & $m t k t$ & /matexet & נתכ & ntk & חתנכ & xtk \\
\hline מצולת & mpwlt & /mapolet & נפל & $n p \mid$ & כפל & $\mathrm{kpl}$ \\
\hline מגבת & mgbt & /magevet & נגב & ngb & חגב & $\mathrm{xgb}$ \\
\hline מפוחית & mpwxyt & /mapuxity & נפח & $n p x$ & טפח & $\theta p x$ \\
\hline הסעה & hSch & /hasa?al & you & $\mathrm{nS} \zeta$ & yog & pSs \\
\hline השרה & hsih & /hashara/ & נשר & กsז & גשר & gsr \\
\hline היכרוח & hykrwt & 'hekerut' & נכר & nkr & זיכר & $\mathrm{zkr}$ \\
\hline Plon & mSwq & /masok/ & pou & $\mathrm{nSq}$ & pos & $\mathrm{pSq}$ \\
\hline הדחה & $h d x h$ & /hadaxa/ & נדח & $n d x$ & nji & $q d x$ \\
\hline מצור & mcwr & /matşor/ & נצר & $\mathrm{nCr}$ & עצר & scr \\
\hline מרזנה & minh & /matana/ & נותנ & $\mathrm{ntn}$ & חתנג & $\mathrm{xtn}$ \\
\hline מטע & $m \theta s$ & Imatal & נטעل & nes & קטע & $q \theta \zeta$ \\
\hline שבשבת & sbsbt & Ishavshevet & נשב & nsb & חשב & $x s b$ \\
\hline הבעה & hbsh & thabaial & לבעי & nbs & טבע & $\theta b \varsigma$ \\
\hline מפץ & $\mathrm{mpC}$ & /mapats/ & צפנ & npc & חפצ & $x p c$ \\
\hline nnon & hSxh & /hasaxa/ & nos & $n S x$ & רח & Sxr \\
\hline מזיק & mzyq & /mazik/ & נזק & $\mathrm{nzq}$ & חזק & $x z q$ \\
\hline הגשה & hgsh & Thagashal & נגש & ngs & הגש & hgs \\
\hline
\end{tabular}


APPENDIX G

Stimuli used in Experiment 6a

\begin{tabular}{|c|c|c|c|c|c|c|}
\hline \multicolumn{3}{|c|}{ Target } & \multicolumn{2}{|c|}{$\begin{array}{c}\text { Morphological } \\
\text { Prime }\end{array}$} & \multicolumn{2}{|c|}{ Control } \\
\hline Word & $\begin{array}{l}\text { Ortho. } \\
\text { Trans. }\end{array}$ & $\begin{array}{c}\text { Phonetic } \\
\text { Trans. }\end{array}$ & Letters & $\begin{array}{l}\text { Ortho. } \\
\text { Trans. }\end{array}$ & Letters & $\begin{array}{l}\text { Ortho. } \\
\text { Trans. }\end{array}$ \\
\hline הליכה & hlykh & /halixa/ & לנ & Ik & הי - ( & hy \\
\hline מחברת & mxbrt & /maxberey/ & חר & $x r$ & מב & $\mathrm{mb}$ \\
\hline התחנף & $h t \times n P$ & /hitxanef/ & נח & $x \Pi$ & תפ & tp \\
\hline מגדל & mgdl & /migdal/ & דל & dl & מגו & $\mathrm{mg}$ \\
\hline מרספרה & mSprh & /masperal & רo & $\mathrm{Sr}$ & מה & $\mathrm{nh}$ \\
\hline סליחה & Slyxh & /slixal & to & Si & לי" & ly \\
\hline תזמורת & tzmwit & /tizmoret & מר & $\mathrm{mr}$ & מת & $\mathrm{mt}$ \\
\hline קציר & qcyr & /katsir & קר & $\mathrm{qr}$ & יר & $\mathrm{yr}$ \\
\hline מחמט & $m \times b \theta$ & Imaxbet & חו & $x b$ & n & $\mathrm{m} \theta$ \\
\hline הגביר & hgbyr & /higbir/ & בר & br & הב & hb \\
\hline סועד & Sw̧d & /soied/ & TO & Sd & الע & w与 \\
\hline תשקיף & hsqyP & /hishkif/ & שק & sq & שי - E - & sy \\
\hline הכתבה & hktbh & /haxtaval & תב & $\mathrm{tb}$ & בה & bh \\
\hline חיפוש & xypws & /xapus/ & חש & $x s$ & in & $x w$ \\
\hline קמצן & $\mathrm{qmeN}$ & /kamtsan & קמ & $\mathrm{km}$ & קנ & $q^{n}$ \\
\hline בריחה & bryxh & /brixa/ & m & $r x$ & 17 & ry \\
\hline משמרת & msmrt & /mishmeret & שר & $\mathrm{sr}$ & מת & $\mathrm{mt}$ \\
\hline משותלה & mstlh & $/$ mishtala/ & שת & st & מש & $\mathrm{ms}$ \\
\hline מרכבה & mrkbh & /merkaval & כב & $k b$ & רה & $\mathrm{rh}$ \\
\hline מגרפה & mgrph & /magrefa/ & $9 x$ & $\mathrm{gp}$ & גה & gh \\
\hline סחיטה & Sxyoh & /sxita/ & no & $S x$ & ס & Sy \\
\hline מרדף & $\operatorname{medP}$ & /mirdaf/ & דפ & $d p$ & ממ & $\mathrm{mp}$ \\
\hline שנקל & swql & /shokel/ & של & sl & ששו & sw \\
\hline צילום & cylwM & ts silum & צ & $\mathrm{cl}$ & לו & Iw \\
\hline טבילה & Bbylh & /tvila/ & בל & bl & טי & $\theta y$ \\
\hline פחרון & ptrwN & /pitaron/ & פר & $\mathrm{pr}$ & פנ & $\mathrm{pn}$ \\
\hline מזבלה & mzblh & /mizbalal & זל & zl & מז & $m z$ \\
\hline הרעיש & hrsys & /hir?ish/ & עש & $\varsigma s$ & שי & ys \\
\hline שליחות & slyxwt & /shlixut & שn & sx & לת & It \\
\hline החמיר & hxmyr & /hixmir/ & nn & $\mathrm{xm}$ & ถ & $h x$ \\
\hline קישר & qysr & /kisherf & קש & qs & קי & qy \\
\hline התלבט & htlb $\theta$ & /hitlabet/ & בט & $b \theta$ & תל & $\mathrm{tl}$ \\
\hline התנהל & ntnhl & /hitnahel/ & נל & $\mathrm{ni}$ & תה & th \\
\hline כניעה & knysh & Ikni?al & נע & $n s$ & כה & kh \\
\hline מכוער & mkwsr & /mexo?arl & בע & $\mathrm{k} \zeta$ & מך & $\mathrm{mk}$ \\
\hline הדפסה & hdpSh & /hadpasal & 05 & $p S$ & הת & $h p$ \\
\hline התמרח & htmrx & /hitmareax & מח & $m x$ & תמ & $\mathrm{tm}$ \\
\hline חלוקה & xlwqh & Ixalukal & חל & $x \mid$ & וק & wq \\
\hline הרשמה & hrsmh & /harshamar & ר? & rs & שה & sh \\
\hline תלמיד & tlmyd & /talmid/ & מד & md & תד & td \\
\hline שידוך & sydwK & 'shidux' & שנ & sk & $T^{4}$ & yd \\
\hline התאים & ht?ym & /hit?irn/ & ות & $t ?$ & הת & ht \\
\hline התרסק & $h t r \$ q$ & /hitrasek/ & po & $\$ q$ & תק & tq \\
\hline רוקחות & rwqxwt & /rokxut & רק & $\mathrm{rq}$ & ת & $x t$ \\
\hline פריחה & pryxh & /prixa/ & פח & $p x$ & $n^{\prime}$ & $y x$ \\
\hline הקצ'ף & hqcyP & /hiktsif/ & צפ & $\mathrm{cp}$ & י & $y p$ \\
\hline דחיסה & dxySh & /dxisa/ & 07 & $d S$ & די & dy \\
\hline העת"ק & hstyq & /he?etik/ & עת & $\varsigma t$ & הק & hq \\
\hline
\end{tabular}




\section{APPENDIX H}

Stimuli used in Experiment $6 \mathrm{~b}$

\begin{tabular}{|c|c|c|c|c|c|c|}
\hline \multicolumn{3}{|c|}{ Target } & \multicolumn{2}{|c|}{$\begin{array}{c}\text { Morphological } \\
\text { Prime }\end{array}$} & \multicolumn{2}{|c|}{ Control } \\
\hline Word & $\begin{array}{l}\text { Ortho. } \\
\text { Trans. }\end{array}$ & $\begin{array}{c}\text { Phonetic } \\
\text { Trans. }\end{array}$ & Letters & $\begin{array}{l}\text { Ortho. } \\
\text { Trans. }\end{array}$ & Letters & $\begin{array}{l}\text { Ortho. } \\
\text { Trans. }\end{array}$ \\
\hline מכבסה & mkbSh & /mixbasa/ & ב. & bs & $2 n$ & $\mathrm{mb}$ \\
\hline הבריש & hbrys & /hivrish/ & בש & bs & בי & by \\
\hline התחדשט & htxds & /hitxadesh/ & חד & $x d$ & הז & hd \\
\hline בושם & bwsM & /bosem/ & שמ & $\mathrm{sm}$ & اש & ws \\
\hline מסגרות & $\mathrm{mSgn}$ & /misgeret & 70 & $S r$ & no & St \\
\hline שאלה & s?lh & /she?ela/ & שא & s? & אה & Ph \\
\hline משחה & $\mathrm{msxh}$ & Imishxa/ & שח & $s x$ & חרה & $x h$ \\
\hline מקלט & mqle & /miklat & קט & $q^{\theta}$ & מל & $\mathrm{m}$ \\
\hline הועבר & hwsbr & /hu?avar/ & لעد & $\varsigma b$ & הע & hs \\
\hline תפירה & tpyrh & $/$ tfira/ & פר & $\mathrm{pr}$ & פה & $\mathrm{ph}$ \\
\hline חשיפה & xsyph & /xasifa/ & פח & $x p$ & in & $x y$ \\
\hline מטריה & mөryh & Imitriyal & מט & $\mathrm{m} \theta$ & רה & $\mathrm{rh}$ \\
\hline הזכיר & hzkyr & /hizkir/ & נר & $\mathrm{kr}$ & 3 & ky \\
\hline הקדים & hqdyM & Thikdim/ & קמ & qm & מי & $y m$ \\
\hline התלבש & htlbs & /hitlabesh/ & לב & ib & תל & tl \\
\hline ספינה & spynh & $/$ sfina/ & פנ & pn & פי & py \\
\hline הזמנה & hzmnh & /hazmanal & $3 \pi$ & $2 n$ & זה & $2 \mathrm{~h}$ \\
\hline התפאר & htp?r & /hitpa7er/ & פא & p? & אח & t? \\
\hline צרבת & crbt & tşarevet/ & רב & $\mathrm{rb}$ & בת & bt \\
\hline מאופר & $M P w p r$ & /meruparl & אר & $\mathrm{Pr}$ & ור & $w r$ \\
\hline רכישה & rkysh & /rexishal & כר & rk & שה & sh \\
\hline שריטה & sryeh & /srita/ & רט & $\mathrm{r} \theta$ & טה & $\theta \mathrm{h}$ \\
\hline סכנה & \$knh & /sakana/ & jo & Sn & כה & kh \\
\hline העליב & hclyb & /he?eliv/ & על & ફ & יב & $y b$ \\
\hline הזריק & hzryq & /hizrik/ & רק & $\mathrm{rq}$ & הז & hz \\
\hline מפגוש & mpgs & /mifgash/ & פיש & ps & מש & $\mathrm{ms}$ \\
\hline התחרש & htxrs & /hitxaresh/ & n & $x r$ & תח & $t x$ \\
\hline שיחק & syxq & /sixek/ & n & $x q$ & יח & $y x$ \\
\hline ממלכה & $\mathrm{mm} / \mathrm{kh}$ & /mamlaxal & מ & $\mathrm{mk}$ & לה & In \\
\hline כ'גון & nygwn & /nigun/ & נג & $\mathrm{ng}$ & גו & $g w$ \\
\hline מגלשה & mglsh & /magleshal & לש & Is & גה & gh \\
\hline מח:רוזת & $m \times r w z t$ & /maxrozet/ & In & $x z$ & II & WZ \\
\hline הקפיץ & hqpyc & /hikpits / & קפ & $\mathrm{qp}$ & הפ & hp \\
\hline מטפלת & meplt & /metapelev & ל9 & $\mathrm{pl}$ & לת & $\mathrm{kt}$ \\
\hline הקלדה & hqldh & /haklada/ & קד & qd & הל & $\mathrm{hl}$ \\
\hline התחשב & $h t x s b$ & Ihitxashev/ & חש & xs & תש & ts \\
\hline קריאה & qry?h & $/ \mathrm{kriPa} /$ & רא & $r ?$ & קי & qy \\
\hline סריקה & Sryqh & /srikal & po & $\mathrm{Sq}$ & הo & Sh \\
\hline בורג & bwrg & /boreg/ & בר & $\mathrm{br}$ & בו & bw \\
\hline הדליק & holyg & /hidlik/ & לק & $\mathrm{lq}$ & min & hq \\
\hline הבריק & hbryq & /hivrik/ & בק & $\mathrm{bq}$ & הב & hb \\
\hline שיכון & sykwn & /shikun/ & $s w$ & sk & ונ & wn \\
\hline חתונה & $x$ twnh & /hatuna/ & ח & tn & תו & tw \\
\hline מפתח & $\mathrm{mptx}$ & $/$ mafteax & no & $\mathrm{px}$ & מפ & $m p$ \\
\hline מלחמה & $\mathrm{mkxmh}$ & /milxamal & לח & $\mid x$ & מה & $\mathrm{mh}$ \\
\hline הותאמן & ht? $\mathrm{mN}$ & /hita?men/ & מנ & $\mathrm{mn}$ & ת & $\mathrm{tm}$ \\
\hline עבדות & $\zeta \mathrm{bdw}$ & Ravdut & עד & $s d$ & עת & 5 \\
\hline שקרן & sqrn & IStakran/ & שק & $\mathrm{sq}$ & ר & $\mathrm{rn}$ \\
\hline
\end{tabular}

